Influences, identity and historiography in Colombia: the reception of Brazilian modernism (1940s-

1960s)

Giaime Botti

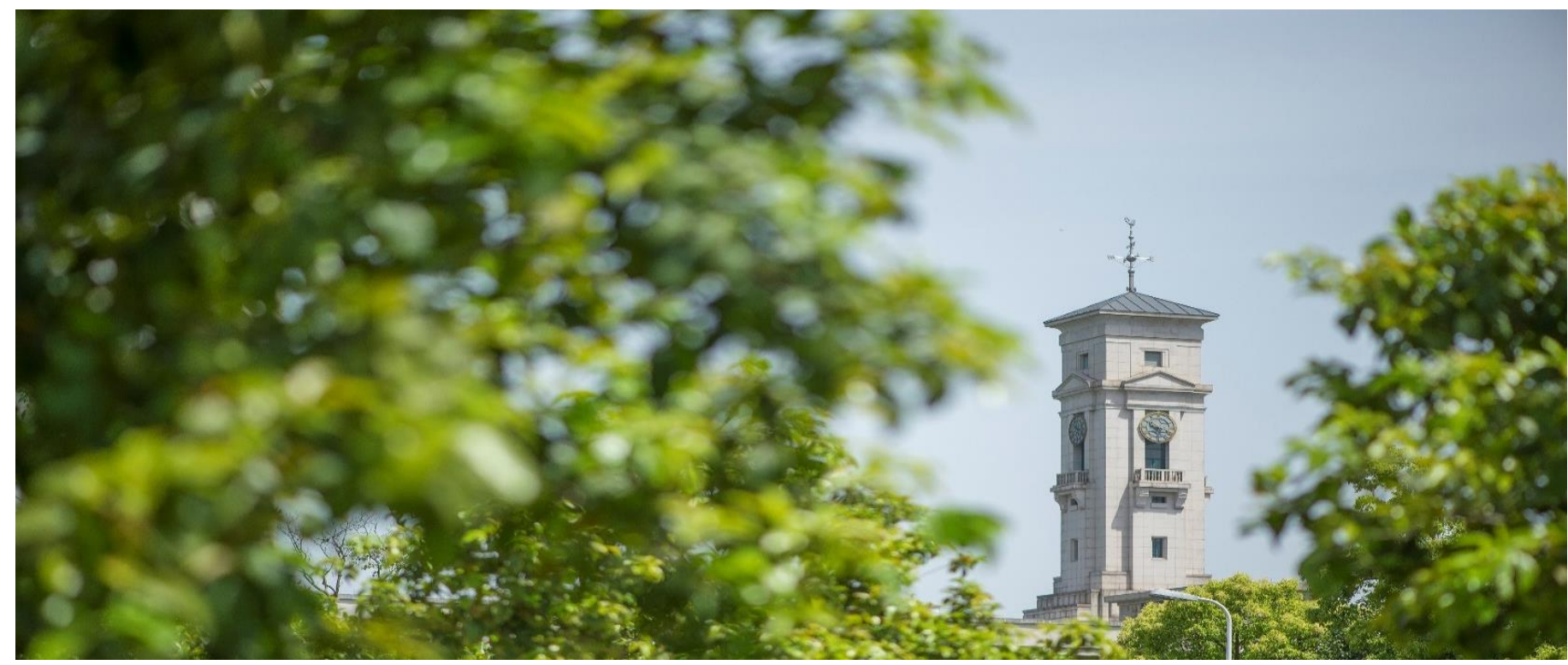


University of Nottingham Ningbo China, 199 Taikang East Road, Ningbo, 315100, Zhejiang, China.

First published 2019

This work is made available under the terms of the Creative Commons Attribution 4.0 International License:

http://creativecommons.org/licenses/by/4.0

The work is licenced to the University of Nottingham Ningbo China under the Global University Publication Licence:

https://www.nottingham.edu.cn/en/library/documents/researchsupport/global-university-publications-licence.pdf 
Influences, identity and historiography in Colombia: the reception of Brazilian Modernism (1940s-1960s)

Giaime Botti, PhD

Assistant Professor

The University of Nottingham Ningbo China

Department of Architecture and Built Environment

giaime.botti@nottingham.edu.cn

ORCID: 0000-0002-3758-8755

This is an Accepted Manuscript of an article published by Taylor \& Francis in The Journal of Architecture on 28th November 2019, available at https:// www.tandfonline.com/doi/full/10.1080/13602365.2019.1684971

To cite this article: Giaime Botti (2019) Influences, identity and historiography in Colombia: the reception of Brazilian modernism (1940s-1960s), The Journal of Architecture, 24:6, 731-755, DOI: 10.1080/13602365.2019.1684971 


\title{
Influences, identity and historiography in Colombia: the reception of Brazilian Modernism (1940s-1960s)
}

Giaime Botti

\begin{abstract}
The reception of Brazilian architectural modernism in Colombia has been dismissed and underestimated by national historiography. This article aims to provide a first overview of the rich system of transnational relations between Colombia and Brazil. Moving from the first acknowledgments of Brazilian architectural production in Colombia - in which triangulations with the USA played an important role, not least after the Brazil Builds exhibition catalogue reached an international audience - this article displays a varied system of transference routes that made the Brazilian-Cariocan modernism one of the main references for Colombian architects during the 1950s. This text examines recognised seminal events and lesser-known facts, highlighting the existence of a wide system of connections. It analyses the reception of the work of Niemeyer and other architects in Colombian magazines and underlines the movements of Colombian architects toward Brazil. It finally recollects a varied group of projects from the 1950s that evidence the diffusion of Brazilian-Cariocan repertories in Colombia among professionals and students. The article highlights how the reception of Brazilian modernism in Colombia should be read as the result of local cases within the global process of modernism's 'tropicalisation'. By doing so, it also discusses the reasons that pushed this process to the margins of the mainstream historiographic narrative.
\end{abstract}

Keywords: architectural history, Latin American modernism, architectural magazines, traveling ideas, Colombian modernism. 


\section{Influences, identity and historiography in Colombia: The reception of Brazilian Modernism (1940s-1960s)}

Giaime Botti

\section{Introduction}

The international reception of Brazilian architectural modernism has attracted a growing interest from scholars, originating a conspicuous number of studies in recent years, mostly focused on the role that national and international architectural journals played in its diffusion in local contexts. Such an investigation is still missing for the case of Colombia, where architects began to insistently look at Brazil from the early 1950s. Even Colombian architectural historiography has overlooked this phenomenon, downgrading it to a limited 'formal influence', 1 or a widespread but temporary 'fashion'. ${ }^{2}$ This phenomenon has never been investigated in terms of its patterns of transference, diffusion, and assimilation, nor its impact on architectural practice measured.

This article aims at providing a first overview on the relationship between the two countries in the architectural field, highlighting not only the function of magazines in spreading ideals and images from Brazil, but also the fundamental role played by Colombian architects educated in that country. In addition, it provides a first outlook on the consequences of this process of assimilation in architectural practice, displaying the particular paths underlying certain projects and the widespread diffusion of these imaginaries among professionals and students. This acknowledgment poses further questions about what should be defined as Brazilian modernism. As will be discussed, a 
certain formal repertoire, far from being exclusively Brazilian, was primarily presented in the 1940 s and $50 \mathrm{~s}$ as 'Brazilian' by a series of influential authors, and it was consequently read as such by Colombian architects. This happened in a context in which international modernism was struggling to renew its image, as evidenced, for instance, by Sigfried Giedion's attempt to frame Finland and Brazil as the new epicentres of modernism. ${ }^{3}$

Several studies support the establishment of a solid comparative framework to understand the reception of Brazilian modernism in other Latin American countries and read these encounters as results of both local and international processes. ${ }^{4}$ These episodes represent particular 'moments of intra-regional dialogue'5 that help in the construction of a more connected history of architecture in Colombia and Latin America. This history emphasises the role of transnational networks like the Centro Interamericano de Vivienda y Planeamiento (CINVA) and the Pan-American Congresses of Architects, and shows the importance of architects' academic and professional mobility as well as of the circulation of magazines.

Finally, this article promotes a revision of intra-Colombian relations in terms of transference paths. Through the Brazilian case, it suggests how the circulation of international models often bypassed Bogotá. Cases in Medellín, Cali, and Barranquilla prove that the interest in Brazilian architecture was dispersed throughout the whole country through multiple and autonomous routes, challenging the centre-periphery paradigm generally proposed by Colombian historiography. ${ }^{6}$

As developments appear varied, intertwined, and overlapping, proceeding chronologically or by authorship would result in a flattened narrative that would not show the true complexity of a process of cultural assimilation that has many 
protagonists and routes. For these reasons, the present article avoids the construction of a simple chronological narrative by displaying a system of interconnected layers.

\section{Early reception: Brazil Builds and the first contacts}

For Colombian architects, the first reported encounter with Brazilian modernism occurred in 1939, when Gabriel Serrano ${ }^{7}$ visited the World's Fair in New York. In the National University magazine Ingeniería y Arquitectura the Colombian described the exhibition mentioning the Chilean, Argentinian, Venezuelan, and Brazilian pavilions as 'the most marvellous', ${ }^{8}$ and showing pictures of Lucio Costa, Oscar Niemeyer, and Josep Lluís Sert's ephemeral building.

The next encounter happened years later, when in 1947 Colombian delegates at the Sixth Pan-American Congress of Architects (Lima-Cuzco) visited the Brazilian Exhibition. ${ }^{9}$ From that moment on, large delegations of Colombian architects participated in the Congresses, originating further occasions to observe advancements in Brazil's architectural production. In 1948, Serrano travelled to Brazil after the Banco de la República board asked his firm, Cusego, to design its Barranquilla headquarter. After his return, three important things happened: an extract of his report from Brazil was published in Proa magazine [Fig. 1]; ${ }^{10}$ Bogotá hosted an exhibition of that material;11 and Serrano had an external wall of his house decorated with Candido Portinari's azulejos [Fig. 2]. According to the report, Serrano visited Rio de Janeiro and Pampulha. His article for Proa featured four architects and nine works with photos and sketches: Oscar Niemeyer's Ministry of Education and Public Health (attributed to him alone), the Boavista Bank in Rio de Janeiro, and the Pampulha complex; Marcelo and Milton Roberto's Brazilian Press Association (ABI) headquarters and Santos Dumont airport in 
Rio; and Lucio Costa's Nova Cintra apartments building in the same city. In the introduction, Serrano highlighted some typical aspects of Brazilian modernism: the design of comfortable and functional buildings, the cooperation between artists and architects, the importance of gardens, the expertise in concrete structures, and the presence of sun-control elements $^{12}$ - all themes that suggest an acquaintance with Brazil Builds. In actual fact, the catalogue of this 1943 exhibition at the Museum of Modern Art in New York, curated by Philip Lippincott Goodwin in collaboration with photographer George Everard Kidder Smith, represented a milestone for the international acknowledgement of Brazilian modernism and provided an interpretation of this architecture that included all the elements mentioned by Serrano. ${ }^{13}$

Nevertheless, other architects had already explored these themes and repertoires, even before that moment and outside of Bogotá. In 1947, Alfonso Caycedo Herrera14 and engineer Ángel Castro Borrero won the competition for the Cali railway station. Their (unbuilt) proposal represented the first published project in Colombia to make explicit reference to Brazilian architecture:

[...] which is logically called functional architecture, of which we have marvellous examples spread all over the world. Among those that most inspired us to develop the project are the Ministry of Education and Public Health in Rio de Janeiro, the Brazilian Press Association (ABI), and the Brazilian pavilion at the World's Fair in New York. Furthermore, the climatic conditions of Brazil, as well as its light coefficient, are quite similar to ours throughout the year; from there we will take its architecture, which has raised extraordinary interest in the world of Modern Art, as a model. 
Currently, Rio de Janeiro's building of the Ministry of Education and Public Health is globally considered the most beautiful monument of our time due to its sobriety of lines. Brazilian architects have solved the issue of excessive tropical light through brise-soleils that, like gigantic shutters, are simultaneously architectural motifs of great attraction. The location of our station is such that the main façade directly receives the afternoon's intense sunlight. This excess brightness and heat of our city forced us to solve the problem with an adequate combination of the famous Brazilian brise-

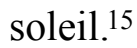

Given the emphasis on climate and on the brise-soleil as a 'famous Brazilian' solution, the reference to the narrative of Brazil Builds appears clear. In fact, in Philip L. Goodwin's book, the first part of the second introduction was primarily dedicated to the problem of sun control, and the first two featured buildings were the Rio de Janeiro Ministry of Education and Public Health and the Brazilian Press Association (ABI) headquarters. ${ }^{16}$

In the same period, in Barranquilla, German émigré Leopoldo Rother ${ }^{17}$ designed the National Building (1946-52), a block with strong affinities with Perret's and Le Corbusier's work, but also reminiscent of Brazil for its urban presence as a freestanding, modern, monumental public building, with an open intermediate floor over a platform. In addition, the project showed a clear concern for natural shading and ventilation, architecturally addressed with the use of concrete latticework and cantilevers. Mauricio Pinilla has highlighted the influence that Brazil Builds had on Rother, who had probably acquired the exhibition catalogue. ${ }^{18}$ 
The role played by Goodwin's book in the early reception of Brazilian architecture in Colombia appears evident. Although it remains difficult to understand its actual availability among architects, ${ }^{19}$ the interpretation of Brazilian modernism and the built references known by Colombians were in perfect agreement with Goodwin. In this respect, Serrano's trip emerges more as a consequence of this first acknowledgment than its cause. In addition, the case of Cali railway station helps to challenge the proposed Bogotá-centric paradigm, showing how architects on the nation's periphery were acquainted with Brazilian modernism before Serrano’s journey.

\section{Brazil in Colombian magazines: building a comparative framework}

Architectural magazines often played a pivotal role in the international diffusion of imaginaries, and the case of Brazilian architecture in Colombia is no exception. An overview of major architectural periodicals in the country not only proves the growing interest toward Brazil that arose in the 1950s, but also helps to cast light on some specific transfer routes.

The second issue of Proa (1946) featured Brazilian architect Pablo Camargo's Ciudad del Periodista in Rio de Janeiro. However, its use in the magazine was directed toward the internal debate on urban planning, contrasting this modern high-density settlement with Bogotás sprawl. ${ }^{20}$ The next article on Brazilian architecture was Serrano's report in 1948. After that, Brazil was not featured for nearly two years, ${ }^{21}$ probably because Proa's founder Carlos Martínez was mainly interested in urban planning, and questions potentially more related to Brazilian modernism, such as the debate on the synthesis of the arts, or the relationship between climate and architecture, were only marginally discussed. ${ }^{22}$ The attention toward Brazilian architects then 
increased to the point of making them the major Latin American reference in the magazine. ${ }^{23}$ The turning point occurred in the early 1950s, when the first Colombian architects who had trained in Brazil returned, and many more started heading there. In 1951, two young graduates, Humberto Flórez Álvarez and Luis José Riaño, from the Rio de Janeiro school and the São Paulo school respectively, edited a monograph on Brazil [Fig. 3]. Eight projects were featured, including works by renowned masters as well as by less famous architects from Rio de Janeiro and São Paulo. ${ }^{24}$ After that, Proa started featuring Brazilian architecture with a certain regularity, thanks to a folder of material brought to Colombia by Riaño. First a project designed by some São Paulo students tutored by Rocha Miranda was published,25 then an award-winning house designed by Henrique Mindlin. The article that featured Mindlin's project mentioned the Paulistana school for the first time in Colombia, ${ }^{26}$ presenting it as a more sober version of the Cariocan, and São Paulo as a city with a different climate and topography to Rio de Janeiro's. 27 Other articles followed, with material also coming from Jacobo Kuperman, another Colombian student based in Brazil, by whom Proa published a school project. ${ }^{28}$ Kuperman, like Flórez and Riaño, acted as a sort of correspondent, bringing many Brazilian projects into Proa. Oscar Niemeyer, Affonso Eduardo Reidy, Sérgio Bernardes, and other more- or less-known architects were featured, and even Zanine Caldas's furniture appeared. ${ }^{29}$ The first São Paulo Biennials were publicised by Proa, ${ }^{30}$ but Colombian participation stagnated. Finally, the seminal event of the competition for Brasilia made it into Proa through material collected by other Latin American magazines. ${ }^{31}$ Another Colombian journal, Revista A, despite its rather national outlook, dedicated a monograph to $\operatorname{Brazil}(8,1957)$, based on material collected by Juan José Vargas, another Colombian student based in Rio de Janeiro. Two texts on 
Oscar Niemeyer, one written by Silvio de Niemeyer, a Brazilian architect living in Medellín and studying at CINVA, and the other from Oscar himself, emphasised the role of the master, although works from Affonso Eduardo Reidy and Francisco Bolonha were also featured. ${ }^{32}$ The presence of Silvio de Niemeyer in Colombia shed light on the relevance that the Centro Interamericano de Vivienda y Planeamiento (CINVA) had in connecting housing and planning professionals from all over the continent, fostering cross-fertilisation. In these years, the Centre was visited by many leading figures, including Félix Candela and Rino Levi.

The reception of Brazilian architecture in Colombian magazines shows a varied system of transference between the two countries. The masters' work was easily acknowledged through international connections with other magazines, while some critical articles were written by Colombian architects close to Proa's editorial board. A more complete overview, often transcending mainstream authors, was provided by a group of young Colombian correspondents. Statistically, the highest presence of Brazilian content in Proa was recorded between 1951 and 1953, after which the number of articles decreased. ${ }^{33}$ This moment coincided with the first two São Paulo Biennials, but also with an initial moment of international criticism. Max Bill's harsh sentences were also reported by Proa after his trip to Brazil in June 1953, ${ }^{34}$ and a special issue of The Architectural Review presented further criticism. ${ }^{35}$ Nevertheless, Brazilian architecture, and Niemeyer's work in particular, continued to enjoy a favourable reception in Colombia for the whole decade. Colombian architect Edgar Burbano quoted Bill's critique in Proa and responded in defence of the seriousness and logic expressed by Niemeyer, and his ability to plastically express the condition of Brazilian society. ${ }^{36}$ Only in 1963, on the occasion of Roberto Burle Marx's exhibition at the 
Bogotá National Museum, did Eduardo Angulo praise the pioneering value of Lucio Costa, Oscar Niemeyer, and Affonso Eduardo Reidy, before declaring the existence of a more mature, intellectual, and elaborate architecture in Latin America, especially in Colombia. 37 As for the rest of Latin America, the reception of Brazilian modernism followed similar but not identical paths. In 1948, the same year that Gabriel Serrano reached Brazil, Peruvian architect Carlos Morales Macchiavello also travelled to there and published an article in the magazine El Arquitecto Peruano. ${ }^{38}$ In Chile, the reception of Brazilian modernism was promoted by Manuel Marchant Lyon, director of the magazine Arquitectura y Construcción, who travelled to Brazil, Argentina, and Uruguay in 1948. After that, his magazine published several Brazilian projects. According to Horacio Torrent in Arquitectura y Construcción, the reception occurred along precise and original lines: Rino Levi's and the Roberto brothers' formal orthodoxy was preferred to Niemeyer's exuberance. ${ }^{39}$ In México, this process started after Mario Pani's trip to Brazil in 1951. As George Flaherty has pointed out, the director of Arquitectura México was looking for an internationally recognised model to confirm his speculation on mass housing and the so-called 'integración plástica'. ${ }^{40}$ These and other international magazines, where Brazil was highly visible from the end of the $1940 \mathrm{~s},{ }^{41}$ were then available to architects and students. At the same time, Proa was featuring Brazil with a coverage incomparable to that of any other country.

In addition, high visibility was granted by at least three exhibitions on Brazilian architecture held in Bogotá in about fifteen years. ${ }^{42}$ The first one, already mentioned, took place after Gabriel Serrano returned from Brazil. In 1960, the Brazilian Ministry of Foreign Affairs hosted the second, which travelled to Bogotá and Caracas. The exhibition displayed Brazilian architectural production from the Portuguese era to the 
foundation of Brasilia through photographs, several models of Oscar Niemeyer's buildings, and a replica of Aleijadinho's prophet Joel statue. ${ }^{43}$ The last exhibition, held in 1963 at the Bogotá National Museum ${ }^{44}$ was dedicated to the work of Roberto Burle Marx, a figure already well-known and with personal acquaintances in Colombia. 45

\section{Complex itineraries: education and travels for a widespread knowledge}

Although the rise of Brazilian architecture as an international reference represented a global phenomenon, a more detailed and diversified view on local processes seems necessary. Colombians started aiming at Brazil in the late 1940s, consolidating this trend in the first half of the 1950s, after the international reception of Brazilian architecture reached its apogee. A reading of Proa shows that during the 1950s a remarkable number of Colombians went to Brazil for their studies, the magnitude of which has only recently been revealed. ${ }^{46}$ More than 20 students have been identified, ${ }^{47}$ but figures may have been higher. 48 These movements were determined by a clear choice of school: the vast majority of Colombians headed for the Universidade Federal do Rio de Janeiro, and only a handful to other cities. Colombians wanted to study architecture in Rio because it was the city of Niemeyer, and many recognised architects had teaching positions in the faculty: Sérgio Bernardes, Ernâni Mendes de Vasconcelos, and Affonso Eduardo Reidy, who taught in the graduate course of urban planning.

A good example of how Colombian architectural practice was influenced by professionals trained in Brazil is visible in the work of Alfonso Noguera and Jorge Santander's office, whose production displayed many typical elements of the Cariocan repertoire after Álvaro Larreamendy, an architect educated in Rio de Janeiro, joined the practice. Their unbuilt project for the Academia de Medicina in Bogotá was crowned by 
an organic water tank akin to the one on top of the Ministry of Education and Public Health in Rio de Janeiro designed by Le Corbusier, Oscar Niemeyer, and others. The house they designed for Antonio Sefair in Bogotá featured other Cariocan elements, albeit contaminated: circular pillars clad with ceramic tiles, a sinuous roof volume inscribed within a thin regular roof sustained by thin columns, an external entrance ramp plus staircase, an internal curved ramp, and the organic design of the garden facing the street. Similar elements also characterised projects they designed for the Banco Cafetero in various cities. 49

Another interesting case is that of Jaime Arrazola Madrid, another Colombian trained in Rio de Janeiro and active in Brazil, Colombia, and Venezuela. His hotel and office blocks can be considered typical examples of 1950s 'tropicalised' international style and are among the few projects realised by Colombians published in Brazilian journals. ${ }^{50}$

While many moved for a long period of time, others travelled only for short visits. Excursions to Brazil were organised for fifth year students of the Colombian National University of Bogotá in 1950 and 1953. As a result, thesis work developed by a group in 1950 presented clear references to Brazilian modernism, as most of the students had travelled to that country in the same year. ${ }^{51}$ Their proposals not only featured typical elements such as the so-called butterfly roof and the cobogó (concrete or masonry latticework), but also included direct references to Brazilian projects. For instance, the two churches proposed by students for the industrial settlements of Paz de Río and Belencito were simplified copies of Oscar Niemeyer's São Francisco (without the three chapels at the rear) ${ }^{52}$ [Fig. 4]. Another student who undertook a similar study trip in 1953, Luis Raúl Rodríguez, was later the architect of the Cúcuta Country Club, a 
‘literal transcription' of Niemeyer's Yacht Club in Pampulha, according to Germán Téllez. 53

In the early 1950s, the broad diffusion of Brazilian models within Colombian architectural schools is striking, probably thanks to students' travels and readings, but not yet to Proa's coverage. Also in Medellín, students from the Pontifical Bolivarian University used Niemeyer's chapel in Pampulha as the basis for a thesis project, ${ }^{54}$ while another student from the local branch of the Colombian National University, Iván Arango, developed a more original project: described as an aspiration to light and air, his design for a church was defined by a series of extruded concrete frames (larger and smaller, alternated) with a triple parabolic arch canopy at the front. 55

Literal transcriptions and more original interpretations prove the dissemination of Pampulha's church as well as other Brazilian models within architectural schools. For instance, two similar projects for a hotel and a holiday residence, designed by students of the Bogotá and the Medellín architecture faculties respectively, displayed generic affinities with Oscar Niemeyer's works in the mixed layouts of regular horizontal blocks and organic elements, in the use of the brise-soleil, and in the organic design of the landscape [Fig. 5]. ${ }^{56}$

The presence of architects trained in Brazil or who had travelled there became significant in many other cities, especially Cali. Here, architects were pushed to look at Brazil for suggested responses to its climate. The exquisite residential and commercial architecture developed in the city from the 1950s found a clear reference in Brazilian modernism. ${ }^{57}$ The well-known firm of Fernando Borrero, Alfredo Zamorano, and Renato Giovanelli designed the Cali Banco de Colombia (1959) as a compact but volumetrically complex corner building with wide shading cantilevers. Its overall 
design shows a certain similarity with Rino Levi and others' IAB building in São Paulo (1947), but also, again, a more generic display of the Brazilian repertoire in the thin vertical brise-soleil of the platform and in the Burle Marx-inspired terrace garden [Fig. 6]. It is interesting to notice a likely personal acquaintance between Levi and these architects. In 1957 Levi visited the CINVA in Bogotá, and also travelled to Medellín and Cali. One year later, an article regarding his visit was published in the Brazilian magazine Acrópole, presenting an apartment building designed by Borrero, Zamorano \& Giovanelli as an example of contemporary Colombian architectural production. ${ }^{58}$

With a group of local architects, Borrero and Giovanelli designed a Country Club on the outskirts of Cali between 1954 and 1958. This Club has been praised as one of the most sophisticated examples of landscape design in Colombia. ${ }^{59}$ The design of the complex displayed similar ideas to that of Cariocan architecture, with formal elements such as light asymmetric V-shaped pillars akin to those used by Oscar Niemeyer in the canopy at Ibirapuera Park built in São Paulo in 1954. The reference appears as much conceptual as formal. The strong horizontal white lines of the building, the well shaded, ventilated and permeable interiors, and the tropical garden displayed a mature assimilation of Cariocan design culture [Fig. 7]. Not surprisingly, Borrero and Zamorano had travelled to Brazil before starting this project, ${ }^{60}$ and many other architects undertook similar journeys.

From Medellín, Raúl Fajardo Moreno, Jaime Greiffenstein, Augusto González, and Reinaldo Posada travelled to Pampulha. ${ }^{61}$ Posada collaborated with Elias Zapata Sierra in the design of the Postobón Factory in Medellín, whose patio displayed a landscape composition à la Burle Marx, with an abstract design of the green and a mosaic on the wall [Fig. 8]. This approach to landscape in the Antioquian capital in the 
1950s was common, as can be seen in the gardens outside Enrique Olaya Herrera airport designed by Zapata, or in the sinuous canopy - clearly inspired by Niemeyer - designed for the Club Unión by an unknown architect [Fig. 9]. Even students from Medellín's Pontifical Bolivarian University noted in a thesis that this widespread language was immediately associated with Brazil:

The evident revolution in [architectural] magazines is bringing us a new form of academicism, more nefarious than that of cornices and volutes. The 'modern style' is already well established among us, and those who manage to introduce in their work those four or five elements that have already become traditional after three years of application, can count on being considered revolutionary artistic geniuses, even if their experience does not go beyond the penultimate year of their education, and their studies and efforts are limited to wholly embracing the work of the most fashionable of the Brazilians, or the latest exaggerated curve of a garden $a ̀$ la Burle Marx. ${ }^{62}$

\section{The adoption of the Cariocan repertoire in Colombia}

The international acknowledgment of the work of many Brazilian modernist architects and the broad dissemination of these references in Colombia started to be felt in architectural practice by the end of the 1940s. A series of projects designed up to the 1960s displayed different degrees of assimilation of themes, repertoires, and principles that after World War II had increasingly been identified as typically Brazilian, although in fact they were mainly characteristic of the so-called Cariocan school, or even just of Oscar Niemeyer's work. The narrative on the brise-soleil, that started with Goodwin's 
Brazil Builds (1943), remained almost unquestioned throughout the following decade. According to Henrique E. Mindlin, who explicitly referred to him in his writings, the open ground floor with pilotis and the use of brise-soleil constituted the 'most conspicuous factors of modern architecture in Brazil'.63 Henry-Russell Hitchcock gave a central position to Cariocan architects in his seminal Latin American Architecture Since 1945, highlighting a formal repertoire based on low paraboloid shell vaults, butterfly roofs, brise-soleil, azulejos, and gardens. ${ }^{64}$ Even critical positions, like those expressed by Max Bill, depicted Brazilian modernism as a style primarily defined by these elements. ${ }^{65}$ Therefore, it should not come as a surprise that during the $1950 \mathrm{~s}$, despite acknowledging different tendencies, Colombian architects understandood Brazilian modernism according to this interpretation, which provided a useful and legitimised architectural repertoire, with a few clear characteristics: the presence of suncontrol devices, the importance of gardens, and the cooperation of architects and artists, as Serrano pointed out in 1948.66 Or, an architecture distinguished by the strong presence of the curved line and the free ground floor, as Edgar Burbano stressed in an article recognising the conceptual overlap between Cariocan architecture and Niemeyer's. ${ }^{67}$

In this respect, the following section can be read as an initial inventory of projects designed in Colombia during a decade marked by a growing interest in Brazil. This inventory includes a few well-known cases already recognised by established Colombian historiography, but expands to other lesser-known projects, in order to discuss this narrative and its restrictive appraisal.

As already mentioned, the Banco de la República headquarters in Barranquilla, designed by Cuéllar, Serrano, Gómez \& Cía after leading partner Gabriel Serrano had 
travelled to Brazil, was completed in 1952 [Fig. 10]. Despite its partitioned ground floor, this office building presented clear references to buildings that Serrano had visited in Brazil. In particular, the four façades presented different systems of sun protection from a deep concrete grid on the Eastern front, to a vertical brise-soleil on the SouthWest facing side - certainly a novelty in Colombia. Other elements of interest were the roof garden and the sinuous flowerbed located in the hall, an obvious adoption of the language of Roberto Burle Marx's garden design. However, the implications of this building were wider: Serrano's idea of replacing massive concrete slabs with hollow biaxial slabs, which finally led to the development of the Reticular Celulado system with Italian engineer Domenico Parma, resulted from Serrano's observation of concrete construction techniques in Brazil.68 It should be noted here that, despite huge differences in the relationship between political power and architecture in Colombia and Brazil, the construction industry in the two countries used similar structural materials and methods, in that they both relied heavily on reinforced concrete.

After the completion of the Banco de la República, other buildings in Barranquilla showed a debt to Cariocan modernism. The most emblematic project was the troubled José Alejandro García and Roberto McCausland's Barranquilla Municipal building, designed in 1950 and completed only in 1959 by Vittorio Magagna and Ricardo González Ripoll with considerable modifications. The original design was a 21storey block raised on 18 circular pillars. In a diagram published both in Proa and in Mejoras, the architects compared two volumetric solutions: one lower with a larger footprint, the other thinner and taller. The latter option, according to the designers, presented many advantages: it freed more ground for public green spaces, it favoured cross ventilation and natural lighting, and it reduced the façade surface exposed to the 
western heat. ${ }^{69}$ The general scheme is redolent of the Ministry of Education and Public Health in Rio de Janeiro: both were located on the edge of their plot and were elevated on circular pilotis; both had two differentiated main façades - one protected by brisesoleil, the other with a curtain-wall; and both had an organic water-tank on the roof and a ceramic mural on the side façade [Fig. 11]. The axonometric diagram used by García and McCausland to justify plot occupation and volumetric choices is also reminiscent of that published in Le Corbusier's Euvre complète to compare traditional forms of plot occupation with what he called 'Nouvelles méthodes réalisées (en cours d'exécution)' for the Ministry of Education and Public Health. ${ }^{70}$ However, by almost halving its height, the final realisation of the Municipal building destroyed the proportions and part of the resemblance.

In addition to these major projects, other buildings featuring various systems of brise-soleil and free-form volumes on the roof were designed in Barranquilla during the same period.71 However, most of this production has remained generally unacknowledged by Colombian historiography, while two other phenomena have been recognised: the diffusion of the brise-soleil throughout the country, even in non-tropical locations such as Bogotá; and the emergence of Oscar Niemeyer's São Francisco church in Pampulha as a model for religious architecture. ${ }^{72}$

The clearest example of unnecessary and decorative use of sun-control elements was probably represented by Esguerra, Sáenz, Urdanéta \& Samper's building for the Servicio Nacional de Aprendizaje (SENA) in Bogotá (1958), a block that employed a multi-layered system of references: from Le Corbusier's brutalist poetic - particularly significant for Germán Samper, who had worked for long time on the Chandigarh project during his stay in Paris - to Brazilian echoes in the differentiated brise-soleil of 
its façades and in the use of an external block of vertical connections, as in Oscar Niemeyer's Conjunto Kubitschek in Belo Horizonte (1951), or the Palácio da Agricultura in São Paulo (1955).

Clearly, while the use of sun-control devices appeared of doubtful benefit in Bogotá, in other parts of the country it was easily justified by the climate. Among the countless cases, it is worth mentioning Enrique Wiesner's Bogotá Bank in the city of Girardot (1951), one of the first buildings published in Proa that displayed a façade with vertical brise-soleil and praised for the way it dealt with the local hot climate. ${ }^{73}$ Or the Miguel de Aguinaga building, designed in 1954-55 by Augusto González Velásquez and others for the firm Ingeniería y Construcciones in the centre of Medellín.

As for religious architecture, Germán Téllez recognised a widespread diffusion of thin concrete shells inspired by Niemeyer after the construction of Juvenal Moya's chapel for the Gimnasio Moderno in Bogotá in 1954. This temporary infatuation resulted in the design of a series of churches in Armenia, Barranquilla, Cúcuta, Medellín, and Sogamoso which more or less adhered to that model. In fact, Moya's chapel had quite an original design, being a Greek-cross plan church. Other examples, like the Torcoroma church in Barranquilla (1958) designed by José Alejandro García (one of the authors of the first proposal for the Municipal building), appeared much less imaginative, with a front recalling Pampulha's façade, albeit without Niemeyer's plastic ability and gracefulness in shaping elements like the canopy and the bell tower. Thus, Niemeyer's church became an unavoidable reference, as an easily reproducible, fashionable, and constructible template. In these decades, many simplified versions were built, such as Cleves, Nariño \& Cía's chapel for the Police in Bogotá, a simple parabolic concrete vault completely open on one side; ${ }^{74}$ or Alfonso López Garrido's 
Nuestra Señora de Fátima church in Cali. ${ }^{75}$ However, the great interest in concrete membrane structures in Colombia had at least one other fundamental reference in Félix Candela, well-known by Colombians and advertised by Proa. Following the work of the two masters, the use of parabolic vaults for a large variety of programmes spread across the country.

The adoption of Cariocan models involved both young and experienced architects, and not only for religious buildings. Pizano, Pradilla \& Caro's Country Club for the Empresa Colombiana de Petróleos in Barrancabermeja76 and their project for a small airport in Guaymaral, both displayed the entire typical Cariocan repertoire. For the airport project, the firm was criticised in Revista A: the roof and the triple vaults resembling Affonso Eduardo Reidy and Jorge Moreira's Viação Férrea do Rio Grande do Sul — were denounced as an unnecessary and confused sculptural gesture. ${ }^{77}$ Still in the 1960s, the Club Social Naval in Cartagena was designed by an unknown architect as a copy of Niemeyer's Pampulha Yacht Club. Undoubtedly, not all the projects and architects mentioned so far met the standards of quality that a selection in the field of architectural history requires. Nonetheless, they do fit in the category of representatives of the period. Fernando Luiz Lara's study on 'popular modernism' in Brazil has helped us understand how this modernist repertoire crossed the borders of professionalism and reached a wider public ready to appropriate it. ${ }^{78}$ In Colombia, all ranks of the profession endorsed and adopted this repertoire. Brazil, known by Colombian architects through international and national publications and direct experience, represented a legitimate, Latin, tropical, and technologically approachable model for more than a decade [Fig. 12]. 


\section{Conclusions: a different canon and a forgotten history}

The system of relations linking Colombia to Brazil is a remarkable case from many points of view. First, because by displaying a broad and varied network of architects' travels and content circulating throughout the Americas, it helps to challenge the view of the continent as composed of non-communicating countries. In this sense, the metaphor of the archipelago as proposed by Luis E. Carranza and Fernando Luiz Lara79 seems fitting. Nonetheless, the projects and influences discussed above show how certain Latin American countries were linked by particular routes of transfer and dialogue for much longer than just the most recent decades.

Second, the networks of relations between Colombia and Brazil allow us not only to highlight the relevance that personal experiences had in transferring and disseminating ideas and imaginaries between countries, but also to emphasise the function that magazines and books had. It is quite clear that Brazil Builds and Proa played different roles. Brazil Builds appears as a key impulse for a first and welldefined dissemination of Brazilian modernism that encountered receptive ears throughout the whole Colombian territory, where architects were trying to adapt modernism to the local environment. In this sense, Bogotá was far from providing any possible paradigm to hot tropical cities like Cali or Barranquilla, and Brazil Builds was a product that did not require any intermediation from Bogotá. On the other hand, national magazines such as Proa and Revista A provided a detailed coverage of Brazil for a decade, thanks to a rich network involving other international periodicals and a generation of young architects with a solid personal acquaintance of Brazil and its architects. 
Finally, the analysis of this case proves how the interest in Brazilian modernism should not be reduced to a simple infatuation for a language and its repertoire. On the contrary, the process of its reception and assimilation was a phenomenon that involved many professionals for more than a decade and marked a whole generation of architects. The impact in terms of formal repertoire was deep, favoured by an understanding of Brazil as a country with similar climatic conditions (at least to major Colombian cities excluding Bogotá) and a construction industry heavily relyiant on concrete rather than steel. Nowadays, this process can be read as both the product of particluar transference routes, and a reflection of the general process of 'tropicalisation' of modern architecture that Jorge Francisco Liernur has presented as a typical feature of the 1950s. 80

Despite this, the architecture designed and built in Colombia according to Brazilian suggestions and principles has remained at the margins of the mainstream historical narrative. This happened because this architecture did not fit into the canons established by historiography. As canonical histories characterised Colombian architecture as simple, austere, and functional ${ }^{81}$ - an argument already used in the 1960 s to counterpose Colombian modernism to the monumental Mexican or the exuberant Cariocan ${ }^{82}-$ it is not surprising that the architectural production discussed here has not found a place in the historiographic construction, which since the publication of Jorge Arango and Carlos Martínez's Arquitectura en Colombia in 1951,83 has always overlapped the concept of 'Colombian' architecture with that of 'Bogotan'. 


\section{Notes and references}

${ }^{1}$ Silvia Arango, Historia de la arquitectura en Colombia (Bogotá: Universidad Nacional de Colombia, 1989), p. 219.

2 Germán Téllez, Critica \& Imagen (Bogotá: Escala, 1998), pp. 92-93.

${ }^{3}$ Decade of New Architecture ed. by Sigfried Giedion (Zurich: Girsberger, 1951). See Jorge Francisco Liernur, 'A New World for the New Spirit: Twentieth-Century Architecture's Discovery of Latin America', Zodiac, 8 (1992), pp. 184-121.

${ }^{4}$ See next section.

${ }^{5}$ Patricio Del Real and Helen Gyger, ‘Ambiguous Territories', in Latin American Modern Architectures: Ambiguous Territories ed. by Patricio Del Real and Helen Gyger (London: Routledge, 2012), pp. 1-29 (p. 3).

${ }^{6}$ In this sense, the otherwise seminal Arquitectura y Estado does reinforce the interpretation of a widespread diffusion of modernism from Bogotá to the periphery through the combined action of the Ministerio de Obras Públicas, Proa and the Colombian National University. See Carlos Niño Murcia, Arquitectura y Estado: contexto y significado de las construcciones del Ministerio de Obras Públicas, Colombia, 1905-1960 (Bogotá: Universidad Nacional de Colombia, 1991). ${ }^{7}$ Gabriel Serrano Camargo (1909-1982) was an influential Colombian engineer and architect, professor at the Colombian National University, Bogotá, and founder in 1933 of the long-lived firm Cuéllar, Serrano, Gómez \& Cía, or Cusego.

${ }^{8}$ Gabriel Serrano, 'Feria Exposición de Nueva York', Ingeniería y Arquitectura, 6 (1939), pp. 20-31 (p. 29). Note that that main Latin American architectural magazines missed it. Neither the Argentinian Revista de Arquitectura, nor the Uruguayan and Cuban Arquitectura, nor Arquitectura México reviewed or even mentioned the pavilion.

9 Silvia Arango, Ciudad y arquitectura. Seis generaciones que construyeron la América Latina moderna (México DF: Fondo de Cultura Económica, 2012), p. 318.

10 'El viaje de Gabriel Serrano al Brasil', Proa, 11 (1948), p. 7.

11 Arango, Historia de la arquitectura en Colombia, p. 219.

${ }^{12}$ Gabriel Serrano, 'Arquitectura moderna en Brasil', Proa, 11 (1948), pp. 7-21. 
13 Philip Lippincott Goodwin, Brazil Builds: Architecture New and Old, 1962-1942 (New York: Museum of Modern Art, 1943). The homonymous exhibition took place in New York from 13 January to 28 February 1943 . On the book, the exhibition and the MoMA's role, see Liernur, 'A New World for the New Spirit' and Patricio Del Real, Building a Continent: The Idea of Latin American Architecture in the Early Postwar (unpublished doctoral thesis, Columbia University, 2012).

${ }^{14}$ Alfonso Caycedo Herrera (1918-2012) graduated from the Colombian National University in Bogotá in 1942 and returned to Cali in 1944. Caycedo had a pivotal role in the city, being one of the founders of the local section of the Colombian Society of Architects and of the University of Valle Faculty of Architecture in 1947. 
15 ‘ [...] lo que se llama lógicamente arquitectura funcional, de la cual tenemos maravillosos ejemplos diseminados por todo el mundo. Entre los que más nos inspiraron para elaborar el proyecto se encuentra el Ministerio de Educación y Salud Pública de Río de Janeiro, el de la Asociación Brasileira de Prensa (ABI) y el pabellón brasileño de la Feria Mundial de New York. Por otra parte, las condiciones climatéricas del Brasil lo mismo que su coeficiente lumínico son durante toda la época del año bastante semejantes a las nuestras; de allí que tomáramos como ejemplo su arquitectura, la cual ha despertado extraordinario interés en el mundo del Arte Moderno. Actualmente el edificio del Ministerio de Educación y Salud Pública de Río de Janeiro está mundialmente catalogado como el monumento arquitectónico más bello de nuestra época por la sobriedad de sus líneas. Los arquitectos brasileros han solucionados los problemas del exceso de luminosidad tropical por medio de quiebra-luces que a manera de persianas gigantescas son al mismo tiempo motivos arquitectónicos de gran atracción. La localización para nuestra estación de pasajeros es tal, que su fachada principal recibe directamente y con toda intensidad los rayos solares de la tarde. Este exceso de luminosidad y de calor en nuestra ciudad nos obligó a solucionar el problema con una combinación adecuada de los famosos quiebra-luces brasileros.' 'Nueva estación del ferrocarril del Pacífico en Cali', Ingeniería y Arquitectura, 76 (1947), pp. 5-8. Author's translation. In 1948, Caycedo and Castro also won the competition for Cali Municipal building with a proposal criticised by competitors on the local press as a copy of three buildings, including the Ministry of Education and Public Health. See Francisco Ramírez Potes, 'La arquitectura racionalista moderna. Cali 1930-1906', CITCE, 1 (1999), 56-80.

${ }^{16}$ Goodwin, Brazil Builds, pp. 81-89.

17 Leopoldo Rother (1894-1978) was a German architect educated in Karlsruhe and Berlin who fled to Colombia in 1936.

${ }^{18}$ Mauricio Pinilla, 'The eminent visitor and a professor of architecture', in Le Corbusier en Bogotá 1947-1951 ed. by María Cecilia O’Byrne Orozco (Bogotá: Fundation Le CorbusierUniversidad de los Andes-Ediciones Uniandes-Pontificia Universidad Javeriana, 2010), pp. $102-13$. 
19 Rogelio Salmona for instance reported that the book was well-known among young architects in those years; see Felipe Leal, 'Conversación con Rogelio Salmona', Bitácora, 9 (2003), pp. 26-33.

20 'La ciudad del periodista en Río de Janeiro. Arq. Pablo Camargo', Proa, 2 (1946), pp. 14-15. ${ }^{21}$ The only exception was Oscar Niemeyer's house in Lagoa, presented in an issue on several architects' own residences: see Proa, 26 (1949).

22 Hugo Mondragón López, ‘Arquitectura en Colombia 1946-1951, lecturas críticas de la revista Proa', Dearq, 2 (2008), pp. 82-97.

${ }^{23}$ From a complete reading of Proa between 1946 and early 1960s, Brazil emerges quantitatively as the main Latin American reference.

24 Oscar Niemeyer's hotel project in Leblon (Rio de Janeiro) and Peixe and Duchen factories (São Paulo, 1950); Mauro Esteves and Hilda Maia’s residence in Recife; Paulo Antunes Ribeiro's Caramuru building (Salvador, 1946); Marcelo, Milton and Mauricio Roberto's Sotreq (Rio de Janeiro, 1949); Almir Gadelha and Acácio Gil Borsoi's Belo Horizonte railway station; Alcides da Rocha Miranda and José de Souza Reis’s Castro Alves Theatre (Salvador, 1948). 25 'Un abrigo público', Proa, 58 (1952), p. 28.

26 With the adjective Paulistana the Colombian author of the article referred to a group of architects close to Henrique Mindlin. This group could have been formed by professionals trained at the Universidade Presbiteriana Mackenzie in São Paulo, and it should not be confused with what later emerged as the 'Paulista school'. See Daniele Pisani, Paulo Mendes da Rocha: Complete Works (New York: Rizzoli, 2015).

27 'Una casa en Sao Paulo. Arquitecto: Enrique E. Mindlin. Sao Paulo', Proa, 58 (1952), pp. 29-31.

28 'Concurso para un monumento en Río de Janeiro. Por Jacobo Kuperman. Alumno arquitecto', Proa, 73 (1953), p. 22.

${ }^{29}$ See Proa 59 and 66 (1952), 68, 73, 75, and 76 (1953), 83 (1954), and 108 (1957).

${ }^{30}$ See Proa, 48 (1951), 66 (1952), 79 (1954), and 103 (1956).

${ }^{31}$ See Proa, 124 (1959).

32 See Silvio de Niemeyer, 'Niemeyer en la Arquitectura Mundial', Revista A, 8 (1957), p. 4 and Oscar Niemeyer, 'Problemas actuales de la arquitectura brasileña', Revista A, 8 (1957), pp. 6-9. 
33 Precisely, in 1951 the monographic issue on Brazil was published, then eight articles in 1952, six in 1953 , three in 1954 , one in 1955 , four in 1957 , three in 1959 , one in 1963 , and one in 1964.

34 Max Bill, 'Declaraciones de Max Bill. Arquitectura. Pintura Mural', Proa, 76 (1953), pp. 26-27. On Bill’s trip see María Amalia García, 'Tensiones entre tradición e innovación: las críticas de Max Bill a la arquitectura moderna brasileña', Concinnitas, 16 (2010), pp. 148-63. 35 Max Bill, 'Report on Brazil', Architectural Review, 694 (October 1954), pp. 235-40.

${ }^{36}$ Edgar Burbano, 'Oscar Niemeyer y sus obras', Proa, 106 (1957), pp. 20-23.

${ }^{37}$ Eduardo Angulo, 'A propósito de la exposición de Roberto Burle-Marx’, Proa, 161 (1963), pp. 24-25.

${ }^{38}$ Carlos Morales Macchiavello, 'Impresiones de un viaje a Brasil', El Arquitecto Peruano, 133 (1948), unpaginated. The journal had already published a report on Brazil after Enrique Mindlin's visit to Lima in 1944.

${ }^{39}$ Horacio Torrent, 'Una recepción diferente. La arquitectura moderna brasileña y la cultura arquitectónica chilena', $A R Q, 78$ (2011), pp. 40-57.

40 George F. Flaherty, 'Mario Pani’s Hospitality. Latin America through Arquitectura/México', in Latin American Modern Architectures, ed. by Del Real and Gyger, pp. 251-69.

${ }^{41}$ See Lauro Cavalcanti, 'Architecture, Urbanism, and the Good Neighbor Policy: Brazil and the United States', in Latin American Architecture, 1929-1960, ed. by Carlos Brillembourg. Contemporary Reflections (New York: Monacelli Press, 2004), pp. 50-59, and María Beatriz Camargo Capello, ‘Arquitectura moderna en Brasil y su recepción en los números especiales de las revistas europeas de arquitectura (1940-1960)', de Arquitectura, 23 (2011), pp. 41-51. 42 It represented a significant number as not many other exhibitions on international architecture were set up in Bogotá in this time frame. As far as we know, only three similar events took place. In 1951, architect Jorge Gaitán Cortés organised an exhibition on US architecture at the University of the Andes (see Germán Téllez, Historia de la Facultad de Arquitectura. Universidad de los Andes. 1948-1998, private paper, courtesy of Maarten Goossens); in 1954 the Banco Obrero de Venezuela displayed its work in the Colombian capital (see Proa, 81 (1954)); and in 1960 a large exhibition organised by the Mexican Architects Association travelled to many countries, including Colombia (see Proa, 140 (1960)). 
43 See 'Noticiário. Arquitetura brasileira em Caracas e Bogotá', Módulo, 3.18 (1960), p. 47.

${ }^{44}$ The only source available on the exhibition is Angulo, 'A propósito de la exposición de Roberto Burle-Marx'. No documentation has been found in the archive of Bogotá National Museum.

${ }^{45}$ For instance, Burle Marx met Colombian architect Jorge Arango several times in Venezuela and was a consultant for the garden design of his house in Miami in 1963; Jorge Arango, Villa Sofia (London: Athena Press, 2003).

${ }^{46}$ Giaime Botti, 'Geographies for Another History: Mapping the International Education of Architects from Colombia (1930-1970)', Architectural Histories, 5.1 (2017) <http://doi.org/ 10.5334/ah.230>.

47 The following graduated from the Universidade Federal do Rio de Janeiro: Tomás Bastilla Arrieta (before 1953), Enrique Aguilar Carrasquilla (before 1955), Marco Antonio Caceres Porras (1957), and Juan José Vargas and Álvaro Larreamendy were active in Bogotá; Eduardo Umaña Mafla (1951), Ernesto and Roberto Patiño Barney (1953 and 1958) were active in Cali; Jacobo Kuperman (1951) in Cartagena; Humberto Flórez Álvarez (before 1951), Germán Arango Londoño (before 1953), Francisco Aguilar Rivero (before 1958), Gregorio Cabrera García (before 1960), Humberto Cabal Paredes (before 1964) were active in Colombia; Cesar Barney Caldas active in Brazil and Jaime Arrázola Madrid (before 1962) were active in Brazil, Colombia, and Venezuela. Luis José Riaño graduated from São Paulo (before 1949). Carlos Silva Escarpetta and Alberto Enrique Díaz Prieto (who left the Universidad Nacional de Colombia after his third year in 1953) graduated from the Universidade Federal de Minas Gerais. Carlos E. Viviescas and Edgar Fajardo Romero graduated from the Universidade Federal do Rio Grande do Sul (Pinzón before 1958 and Romero before 1963). Hernando Amezquita Rojas graduated from the Universidade Federal de Pernambuco, (before 1962). In addition, José Joaquín Padilla Tascón, registered as an architect in Cali, trained in Niemeyer's Atelier, while Silvio de Niemeyer was a Brazilian architect active in Medellín and a student at CINVA in Bogotá. 
48 'Notas editoriales. Escuelas de arquitectura', Proa, 56 (1952), p. 9. The article mentioned the presence of about a hundred Colombians in Brazilian schools, a number that appears too high considering that in 1965 there were less than 1,200 architects registered at the Consejo Profesional Nacional de Arquitectura y sus Profesiones Auxiliares-CPNAA.

49 These projects were presented in Moderna Bogotá arquitectónica (Bogotá: Suramericana Editores, 1960), pp. 78-87.

50 'Hotel del Rio, Girardot, Côlombia. Arq. Jaime Arrázola Madrid', Habitat, 26 (1956), pp. 48-50; 'Edifício Petroleiro, Maracaibo, Venezuela. Projeto: Arqs. Jaime Arrázola Madrid e Lando Delle Cave', Habitat, 51 (1958), pp. 8-9 and 'Edifício Montielco, Maracaibo, Venezuela', Arquitetura e Engenharia, 47 (1957), pp. 26-27.

51 As a matter of fact, eight of the eleven students who designed this project were among the 28 who requested permission to travel to Brazil in 1950. Information from the Archivo Central e Histórico de la Universidad Nacional de Colombia (Bogotá), Faculty of Architecture, correspondence books 1950 and 1953.

52 ‘Estudio urbanístico y arquitectónico de Paz de Río \& Belencito. Promoción de 1950 Facultad Nacional de Arquitectura', Proa, 54 (1951), pp. 11-25.

53 Téllez, Critica \& Imagen.

${ }^{54}$ See Victoria Faciolince et al., 'Plan Piloto de Caldas', Universidad Pontificia Bolivariana, 58 (1950), pp. 414-33 (p. 430 ff.).

55 'Iglesia para unidad vecinal. Proyecto de Iván Arango', DYNA, 67 (1953), pp. 43-44. The canopy resembles that designed by Affonso Eduardo Reidy and Jorge Moreira for the Viação Férrea do Rio Grande do Sul (Porto Alegre, 1944).

56 See 'Hotel de veraneo. Arquitectos: Hernando Acosta Sánchez, Hernando Benincore Cortés, Yalmar Elsin Londoño', Proa, 41 (1950), pp. 20-23, and 'Colonia de vacaciones. Iván Escobar. Facultad Nal. de Arquitectura. Anteproyecto', Pórtico, 8 (1951), pp. 16-17. 57 Pedro Gómez Arango and Pablo Buitrago Gómez, Casas modernas en Cali. Modelos y paradigmas (Cali: Universidad del Valle, 2011), p. 56. 
58 Acrópole, 'Arquitetura na Colombia', Acrópole, 234 (1958), pp. 224-25. The article praised the quality of Colombian architectural production and briefly reported Rino Levi's travel. According to it, the Brazilian architect reviewed CINVA's students on a social housing project in Bogotá and on the study of a favela in Cali; in addition, he gave two lectures in Bogotá, one in Medellín and two in Cali, about urbanism, hospital architecture and applied acoustics (see also Proa, 113 (1957)).

59 Eduardo Samper Martínez, Arquitectura moderna in Colombia: Época de oro (Bogotá: Diego Samper; Vancouver: Noa Noa: 2000), p. 136.

60 Samper, Arquitectura moderna in Colombia.

${ }^{61}$ Cristina Vélez Ortíz, Diego López Chalarca, Mauricio Gaviria Restrepo, Nathalie Montoya Arango, Arquitectura moderna en Medellín 1947-1970 (Medellín: Universidad Nacional de Colombia, 2010), p. 23.

62 'La anotada revolución de revistas nos está desembocando a una nueva academia, más nefanda que la de la moldura y la voluta. Entre nosotros ya se unificó el "estilo moderno" y quien logra introducir en su obra los 4 o 5 elementos que ya son tradicionales con tres años de aplicación, puede contar con que la "gente" le reputa como uno de los genios revolucionarios del arte, aunque su experiencia no traspase el penúltimo año de facultad, ni su estudio y sus desvelos vayan más allá de haber tragado entero el trabajo del brasilero de moda o la última curva empalagosa de un jardín de estilo Burle Marx.' Manuel De Andreis Lanao et al., 'Análisis de una experiencia', Universidad Pontificia Bolivariana, 68 (1953), pp. 389-405. Author's translation.

${ }^{63}$ Henrique Ephim Mindlin, Modern Architecture in Brazil (New York, NY: Reinhold, 1956), p. 11.

${ }^{64}$ Henry-Russell Hitchcock, Latin American Architecture: Since 1945 (New York: Museum of Modern Art, 1955), pp. 30-37.

${ }^{65}$ Zilah Quezado Deckker, Brazil Built: The Architecture of the Modern Movement in Brazil (London: Spon Press, 2001), p. 165.

66 Serrano, 'Arquitectura moderna en Brasil'.

${ }^{67}$ Burbano, 'Oscar Niemeyer y sus obras'. 
68 Diana María Bustamante Parra, La profundidad de la envolvente (unpublished master's thesis, Universidad Nacional de Colombia, Medellín, 2014), pp. 72-75.

69 Roberto McCausland, 'Exposición de motivos y razones sobre la forma como fue diseñado el Palacio Municipal', Mejoras, 153 (1950), pp. 22-37. See also 'La nueva Casa Municipal de Barranquilla. Arquitectos: Roberto McCausland, José A. García. Ingenieros: E. González Rubio, Enrique Díaz Granado', Proa, 34 (1950), pp. 17-21.

70 Le Corbusier and Pierre Jeanneret, Euvre complète, 1934-1938 (Zurich: Girsberger, 1945), p. 81.

71 Some examples from the 1950s-1960s decades include the Federación Nacional de Cafeteros, with a curved volume on top, akin on the one of the nearby Departmental Govern building designed by Jairo Henao; the Banco Cafetero, with a varied system of horizontal and vertical brise-soleil and a sculptural Candela-like paraboloid on the roof built by the construction firm Cornelissen, Salzedo \& Cía, and Fernando Martínez’s Caja Agraria (1961-65), a mature and original synthesis between the Brazilian tradition of sun-control and a layout strongly indebted to Alvar Aalto and Hans Scharoun.

72 Téllez, Critica \& Imagen.

73 'Banco de Colombia en Girardot. Arqts. Wiesner \& Cía S.A.', Proa, 52 (1951), pp. 20-21. 74 Published in Moderna Bogotá arquitectónica, p. 95. Both Guillermo Cleves Lambardi and Luis Londoño Convers received authorisation to travel to Brazil while students at Bogotá National University.

75 Published in Lo mejor del urbanismo y de la arquitectura en Colombia ed. by Plinio Mendoza Neira (Bogotá: Librería Colombiana Camacho Roldán, 1970).

${ }^{76}$ An elevation is visible in Samper, Arquitectura moderna en Colombia, p. 85.

77 'Proyecto del aeroclub en Guaymaral. Arquitectos: Pizano, Pradilla y Caro', Revista A, 1 (1955), pp. 24-26.

${ }^{78}$ Fernando Luiz Lara, The Rise of Popular Modernist Architecture in Brazil (Gainesville, FL: University Press of Florida, 2008). 79 See the conclusions of Luis E. Carranza and Fernando Luiz Lara, Modern Architecture in Latin America: Art, Technology and Utopia (Austin, TX: University of Texas Press, 2014). 
80 Jorge Francisco Liernur, 'Fiebre tropical. Nuevos trayectos y nueva geografía en la cultura arquitectónica internacional como consecuencia de la Segunda Guerra Mundial (1940/1960)', in Viajes en la transición de la arquitectura española hacia la modernidad: actas preliminares, Pamplona, 6-7 mayo 2010, Escuela Técnica Superior de Arquitectura, Universidad de Navarra ed. by José Manuel Pozo Municio and Héctor García-Diego Villarías (Pamplona: T6 Ediciones,2010), pp. 49-56.

81 Hugo Mondragón López and Felipe Lanuza Rilling, ‘El intrincado juego de la identidad. Para una arqueología de la arquitectura colombiana', Dearq, 3 (2008), pp. 2-15. See also Jorge Francisco Liernur, 'Architectures for Progress: Latin America, 1955-1980', in Latin America in Construction. Architecture 1955-1980 ed. by Barry Bergdoll et al (New York, Museum of Modern Art, 2015), pp. 68-89.

${ }^{82}$ Germán Samper Gnecco, 'Prólogo', in Carlos Martínez, Arquitectura en Colombia (Bogotá: Ediciones Proa, 1963), p. 3.

83 Jorge Arango and Carlos Martínez, Arquitectura en Colombia (Bogotá: Ediciones Proa, 1951). 


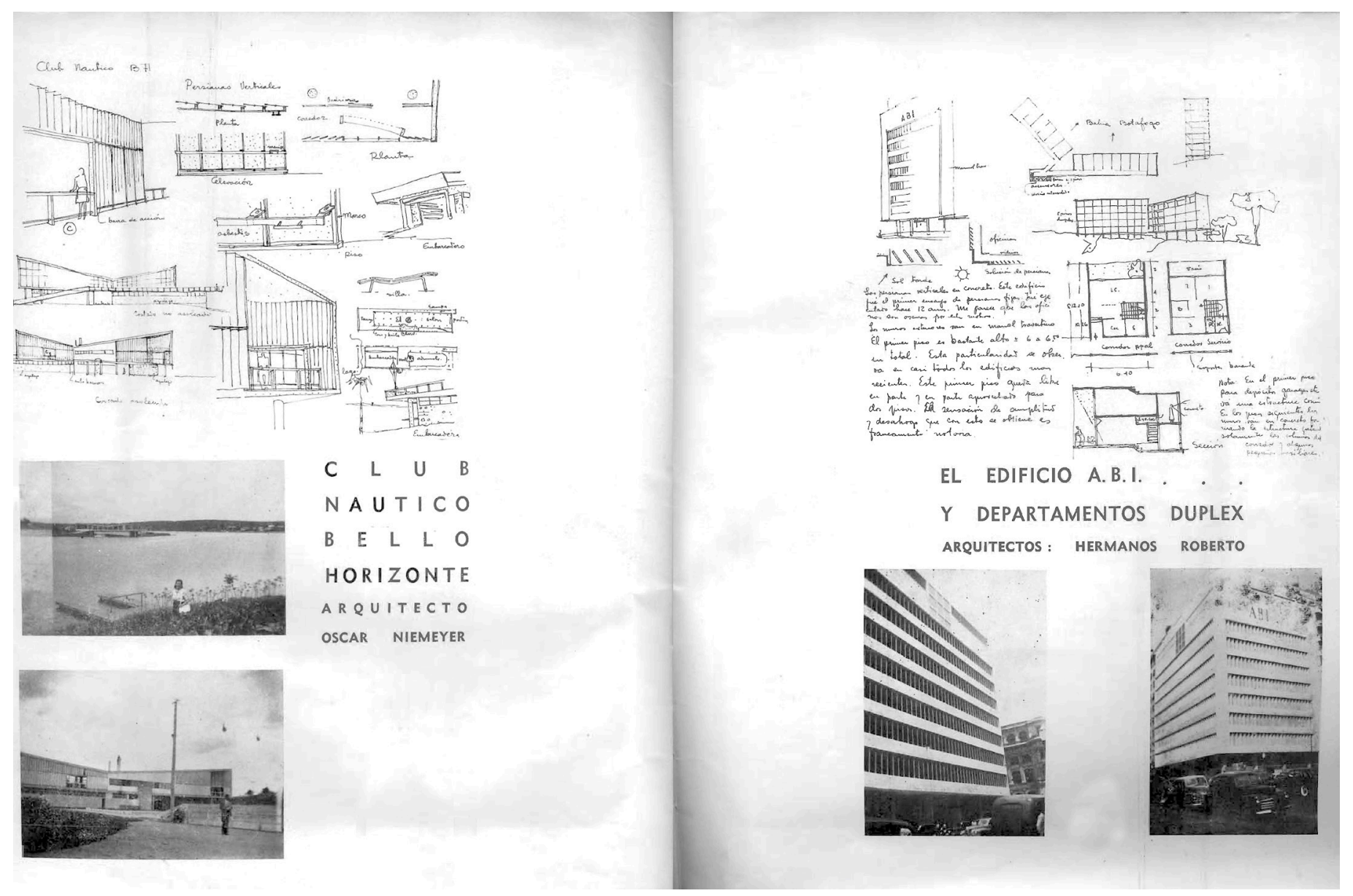

Figure 1. Pages from Gabriel Serrano’s report from Brazil. Proa, 11 (1948), pp. 20-21. Courtesy of Proa.
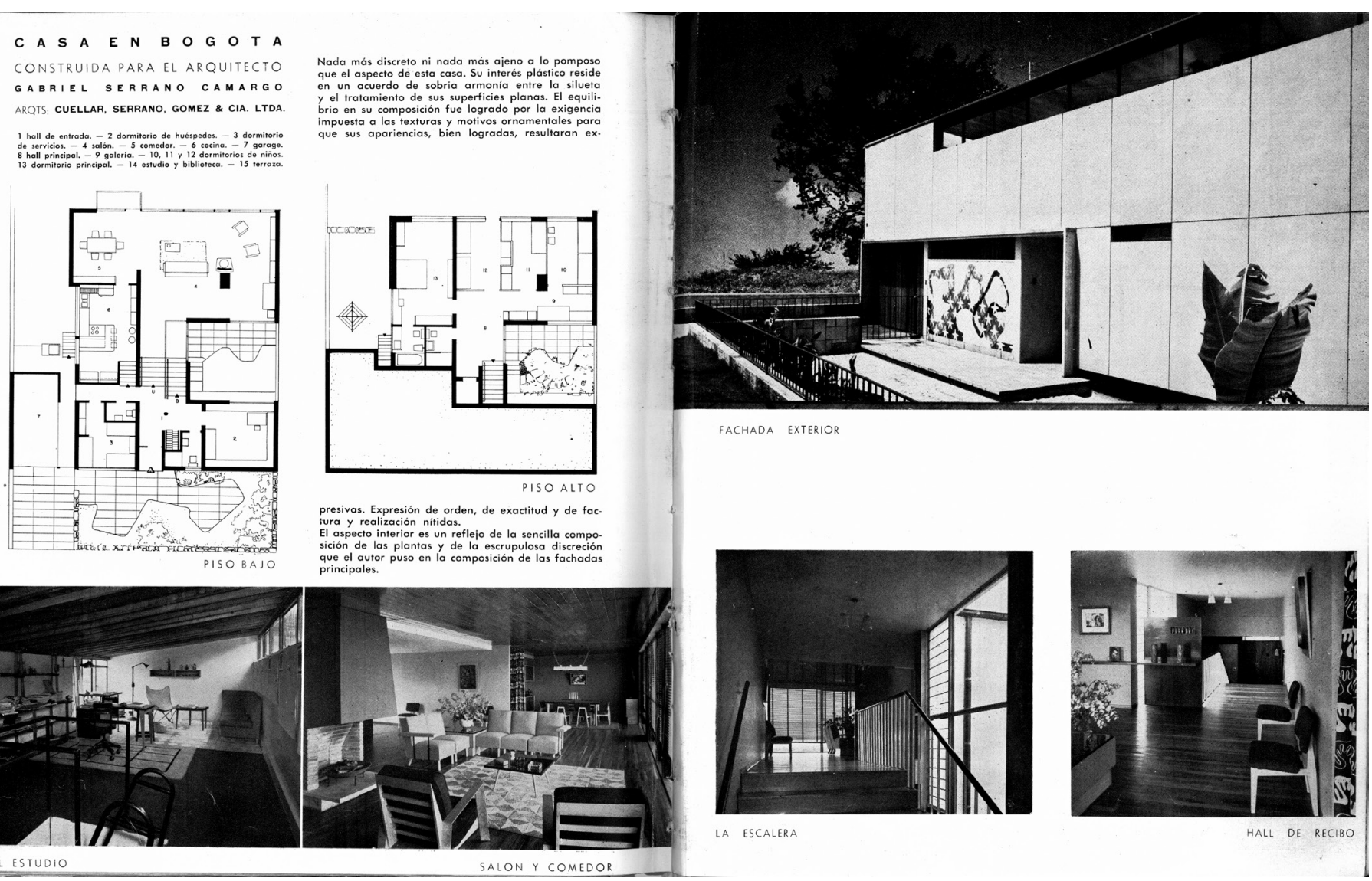

Figure 2. Gabriel Serrano house in Bogotá featuring Candido Portinari’s azulejos on the external wall. Proa, 53 (1951), pp. 10-11. Courtesy of Proa. 


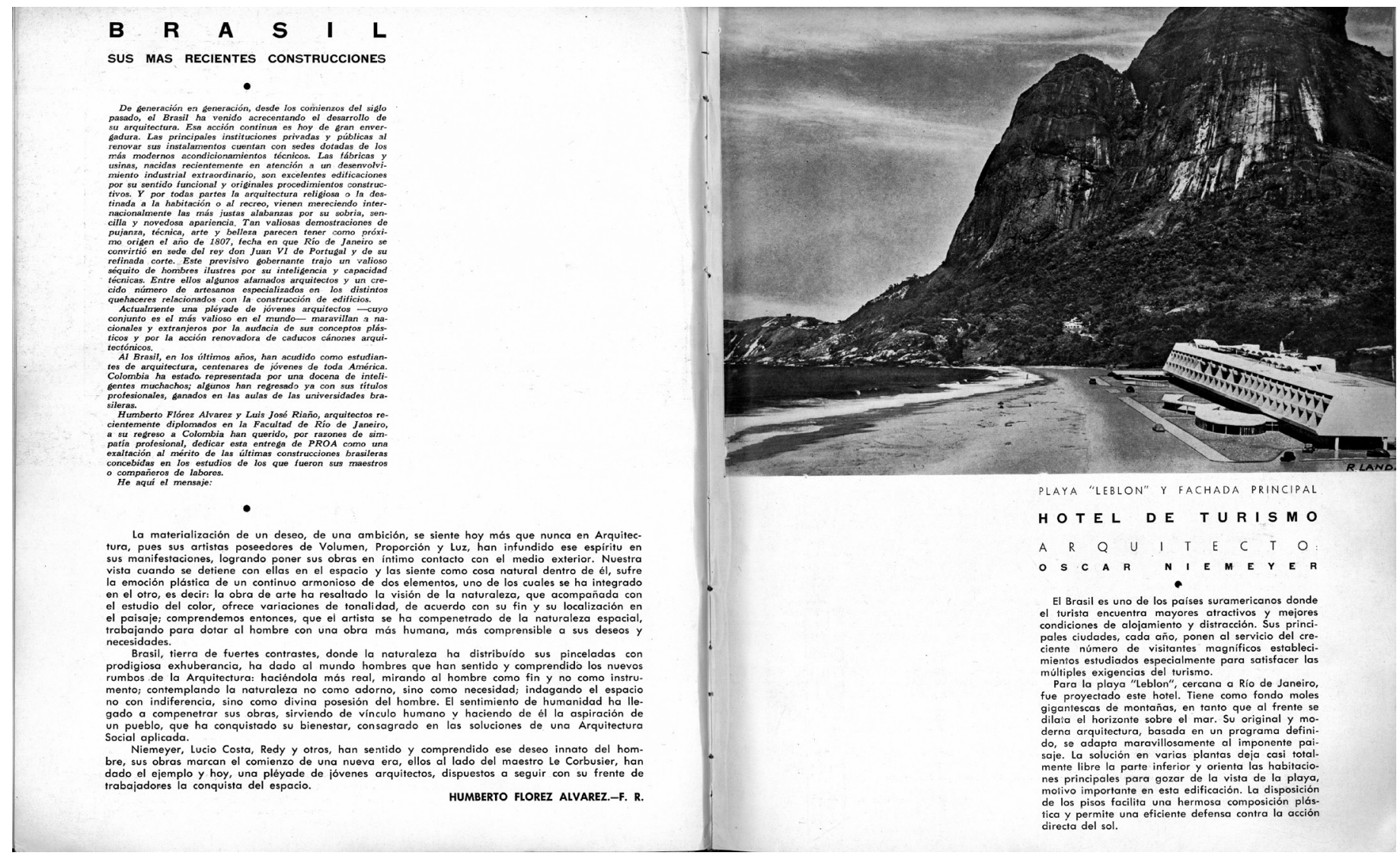

Figure 3. The report from Brazil by Colombian students Humberto Flórez and Luis José Riaño. Proa, 47 (1951), pp. 10-11. Courtesy of Proa.

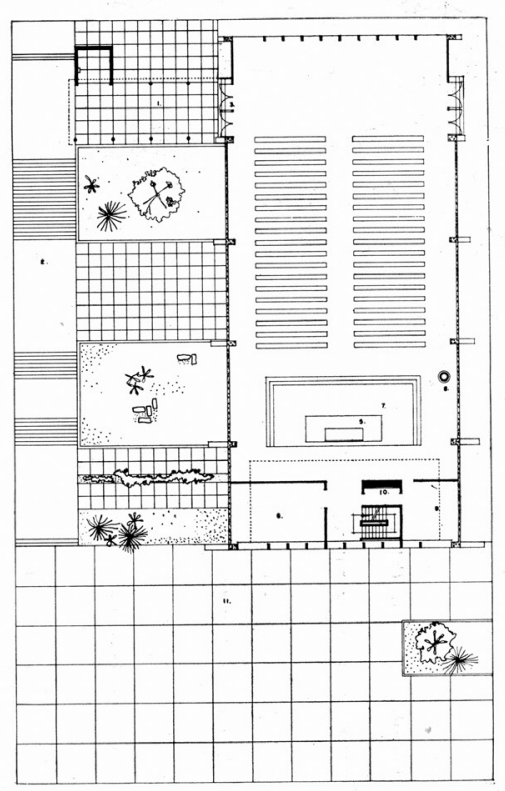

PAZ DE RIO LA IGLESIA

1 atrio -2 acceso -3 entrado 4 navo -5 altar -6 sacristia tepositio -10 vestier -11 pla leposito
Figure 4. A project for a church by students who had previously travelled to Brazil presented at the Colombian National University, Bogotá. Proa, 54 (1951), p. 16. Courtesy of Proa. 


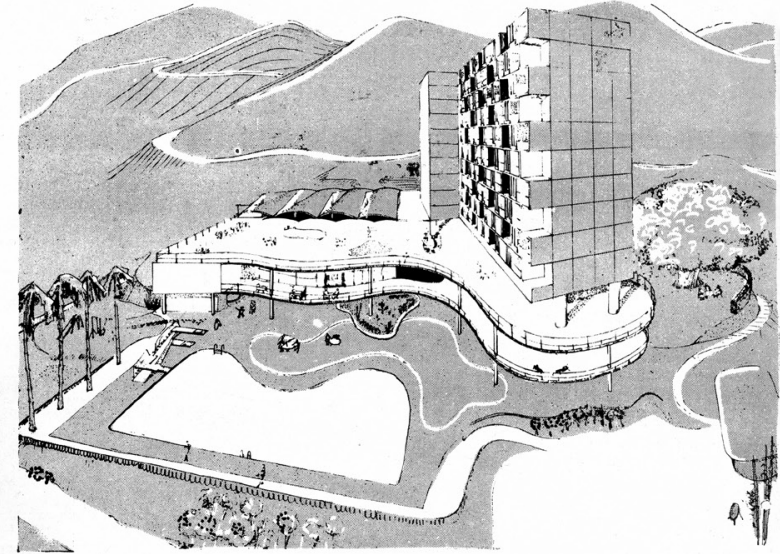
CONJUNTO

H O T E L D E V ERAN E O

Las Mesitas es una pequeña y reciente estación veraniega de los
bogotanos. Situada a corta distancia de la capital $-60 \mathrm{~K}$.- puede ofrecer una grata temperatura media de $25^{\circ} \mathrm{C}$. y dilatados panoristas, inversionistas y para gentes de negocios. Para negocio ha estudiado este hotel de recreo. El proyecto ofrece muchos a de dependencias (100 habitaciones para dos personas en un sec. tor de 9 pisos, 30 apartamentos duplex para tres personas en muy modernas, comedores, bares, salas de reposo, lugaress de recreo, etc.), bien orientadas y estudiadas parán y se rindió
comodidades. Se acató la accidentada topografía nos $y$ menospreciado por muchos, en esta ocasión

ravillosa y adorno del paisaje.
los autores del proyecto, tres jóvenes alumnos-arquitectos, han

A RQUITECTOS: HERHAHOO ACOSTA SANCHEL heRNAHOO BENINCORE CORTES YALMAR ELSIN LONONANO ejecutado su primer encargo con un estudio en el que son notorios jos inspiran simpatía por la franqueza de la composición,

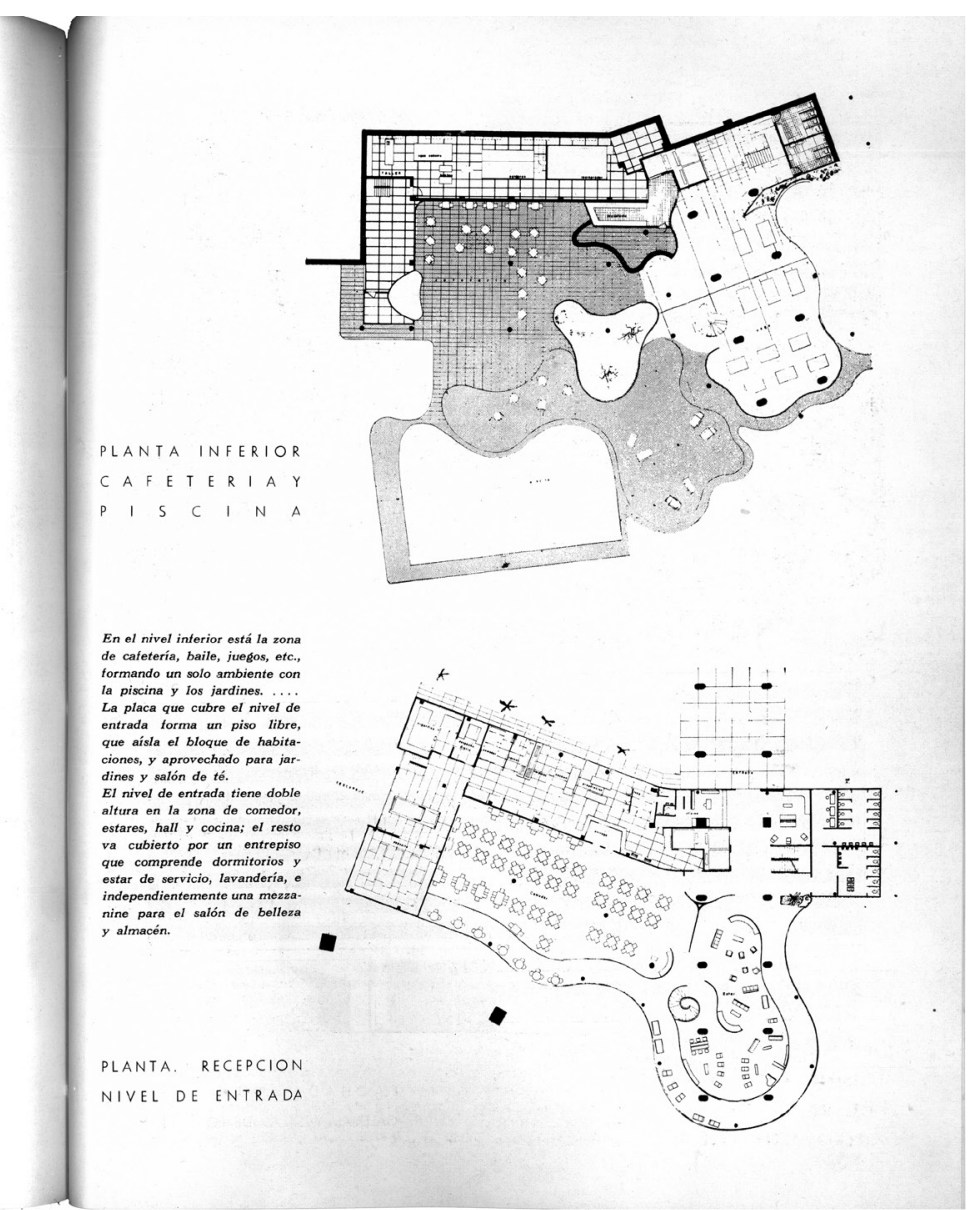

Figure 5. A project for a hotel by young Colombian architects. Proa, 41 (1950), pp. 20-21. Courtesy of Proa.

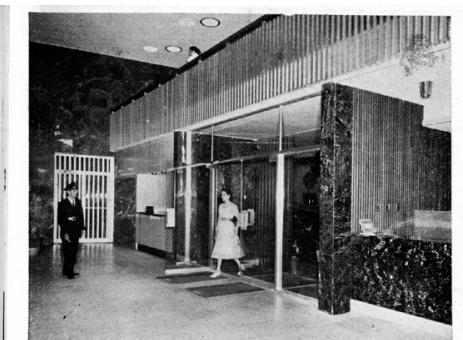

BANCO DE COLOMBIA EN CALI

ARQUITECTOS: BORRERO - zaMORANO - GIOVANELLI

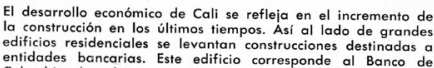

Es una edificación cómoda y bien diseñada. Consta de un só-

Es una edificación cómoda y bien diseñada. Consta de un só-
tano en ee cual se encuentran las bovedas y los archivos de
cuidado; en el primer piso estrá el despacho para el püblico,

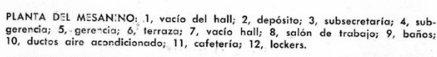
FANTA TIPO: 1, hall; 2, oficinas; 3, baño

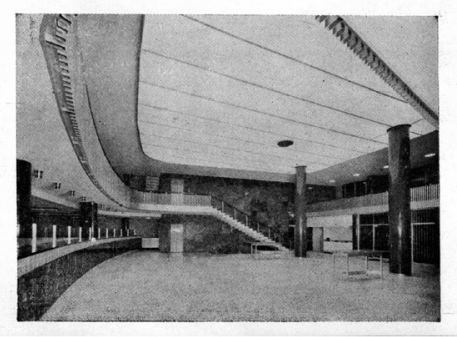

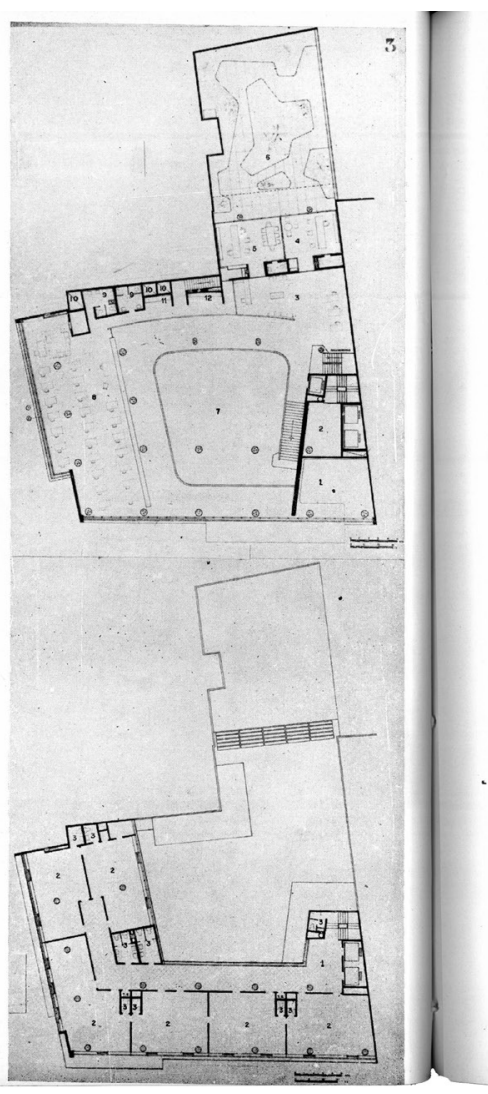
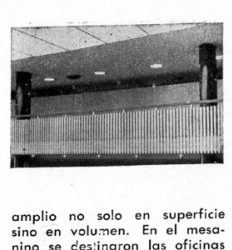

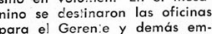

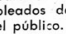

Los seis pisos restantes fueron
estrdidicdoss para renta, en for
ma de oficinas particulares.

La estructura es en concreto
se ha pues:o especial cuidado
en el diseño de las fachados
para con róar lo assoleación. E
los dos primeros pisos del ed.

los dos primeros pisos del edi-
ficio se han colocado persianas
en lámina que a la vez que impiden la entrada del sol son
elementos de seguridad para el

En los pisos restantes se han diseñado voladizos en concree
los que permiten la colocación
de ventanoles de mayor
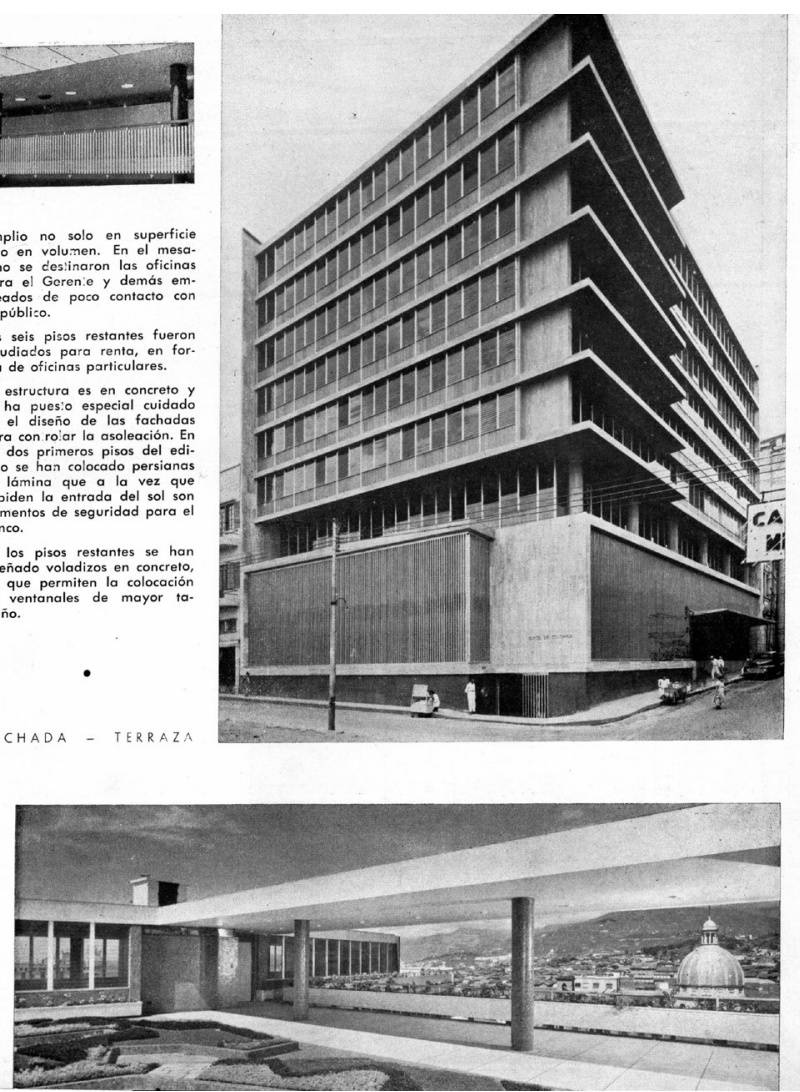

Figure 6. Fernando Borrero, Alfredo Zamorano, and Renato Giovanelli's Banco de Colombia in Cali. Proa, 128 (1959), pp. 18-19. Courtesy of Proa. 


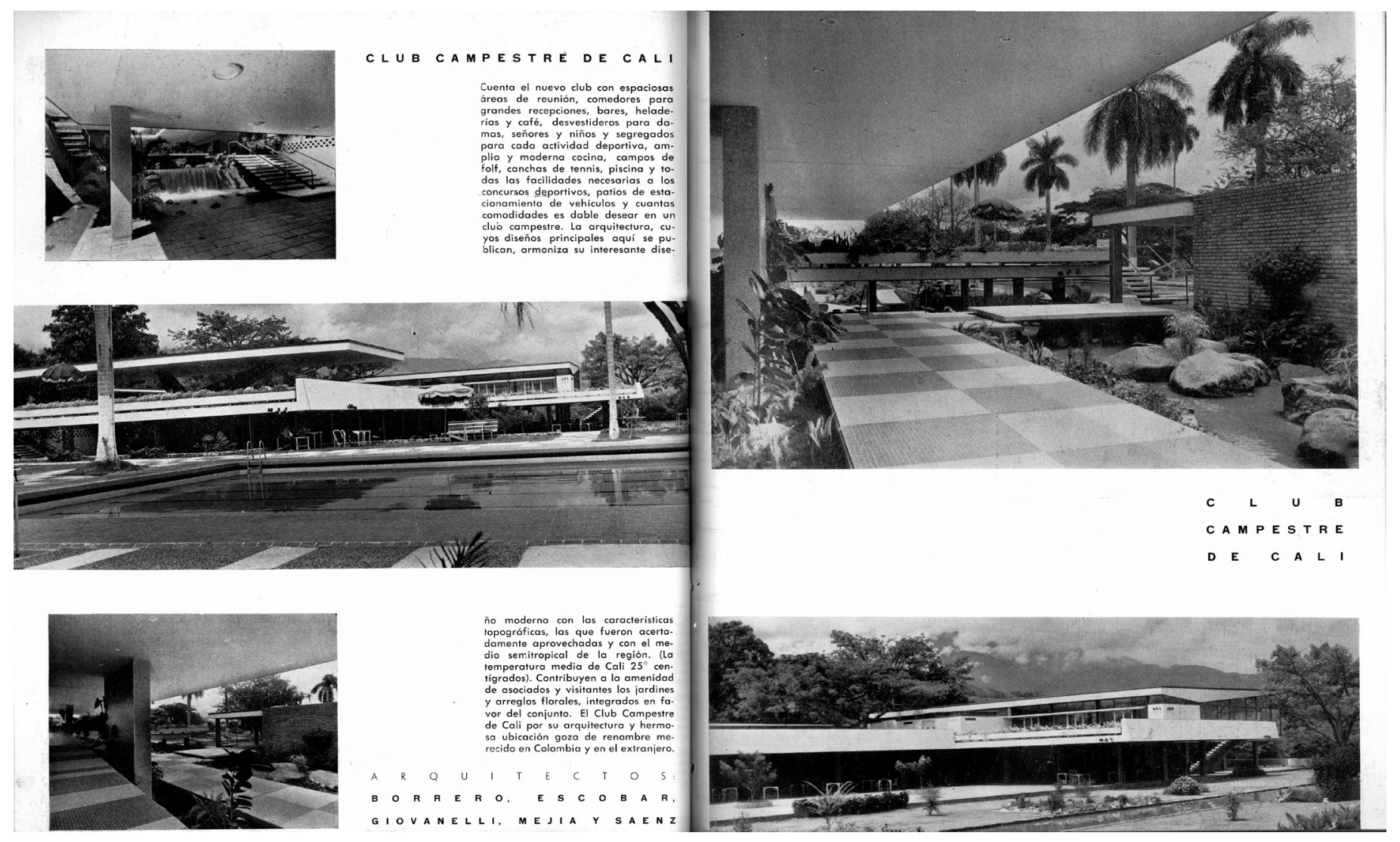

Figure 7. Cali Country Club designed by Fernando Borrero and Renato Giovanelli with Iván Arango, Dario Mejía, and Jaime Sáenz. Proa, 156 (1962), pp. 14-15. Courtesy of Proa.

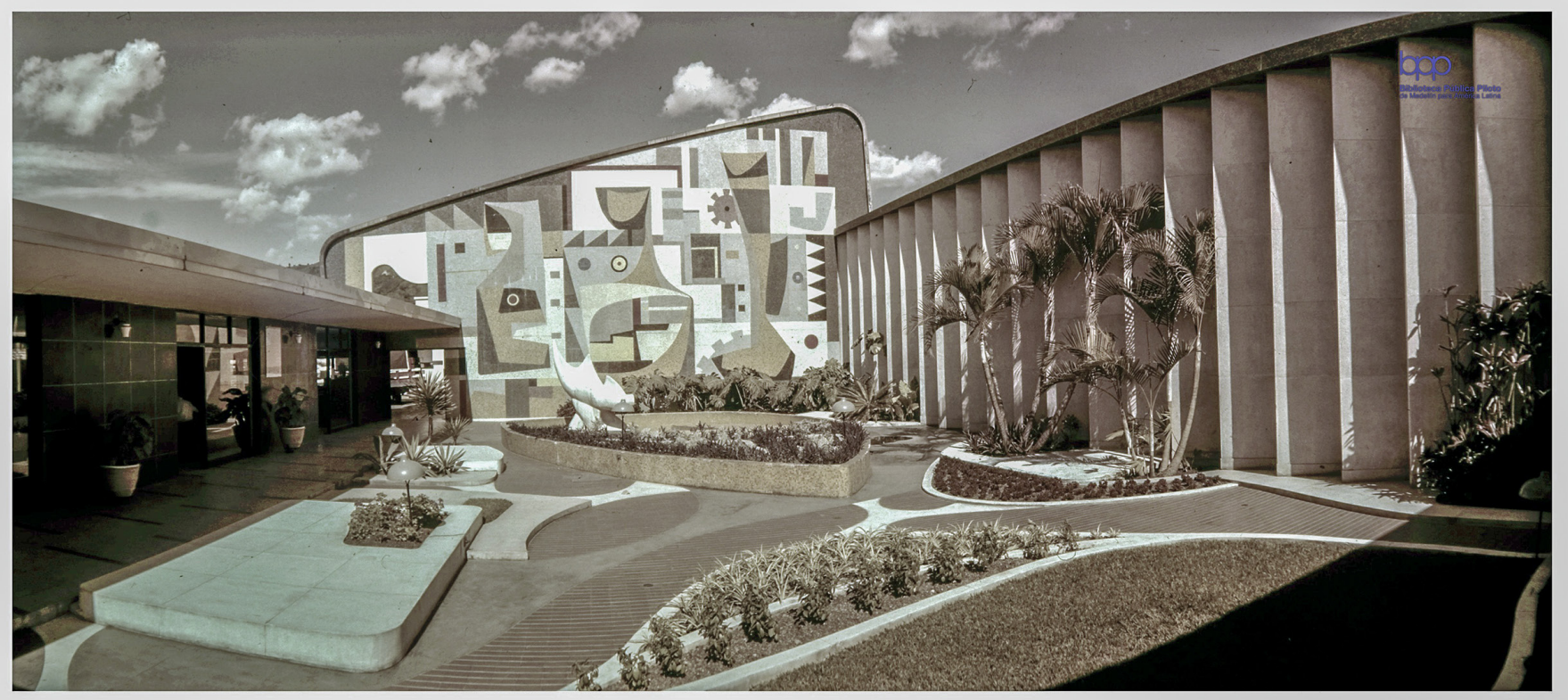

Figure 8. Gardens of the Postobón factory, Medellín, designed by Elias Zapata Sierra with Raúl Posada (1950s). Photography by Gabriel Carvajal Pérez. Fabrica de Postobón. Archivo Fotográfico Biblioteca Pública Piloto de Medellín. BPP-F-004-0115. 


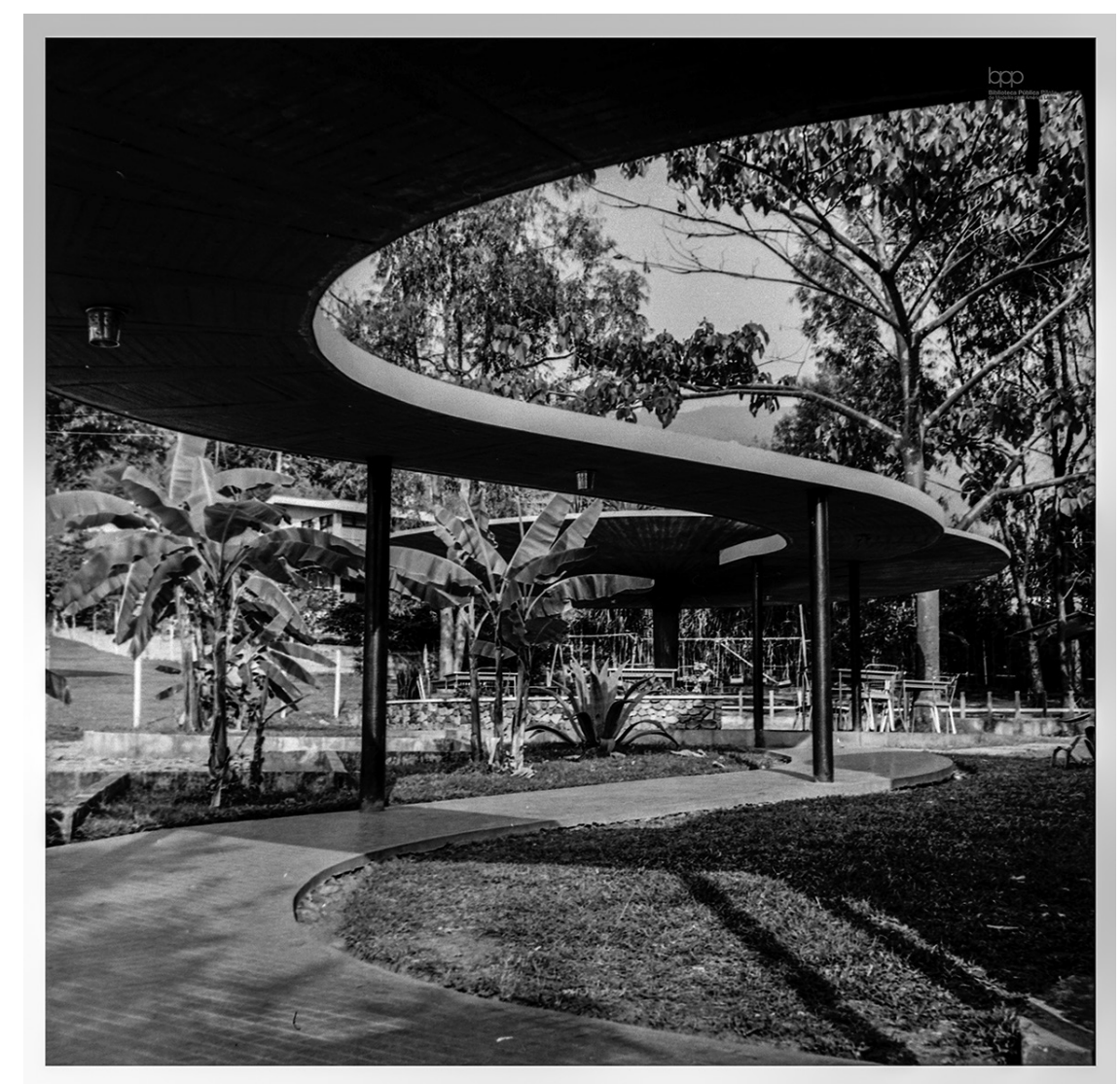

Figure 9. Gardens of the Club Unión, Medellín (1950s). Photography by Horacio Gil Ochoa. Jardines Club Unión. Archivo Fotográfico Biblioteca Pública Piloto de Medellín. BPP-F-006-0367.
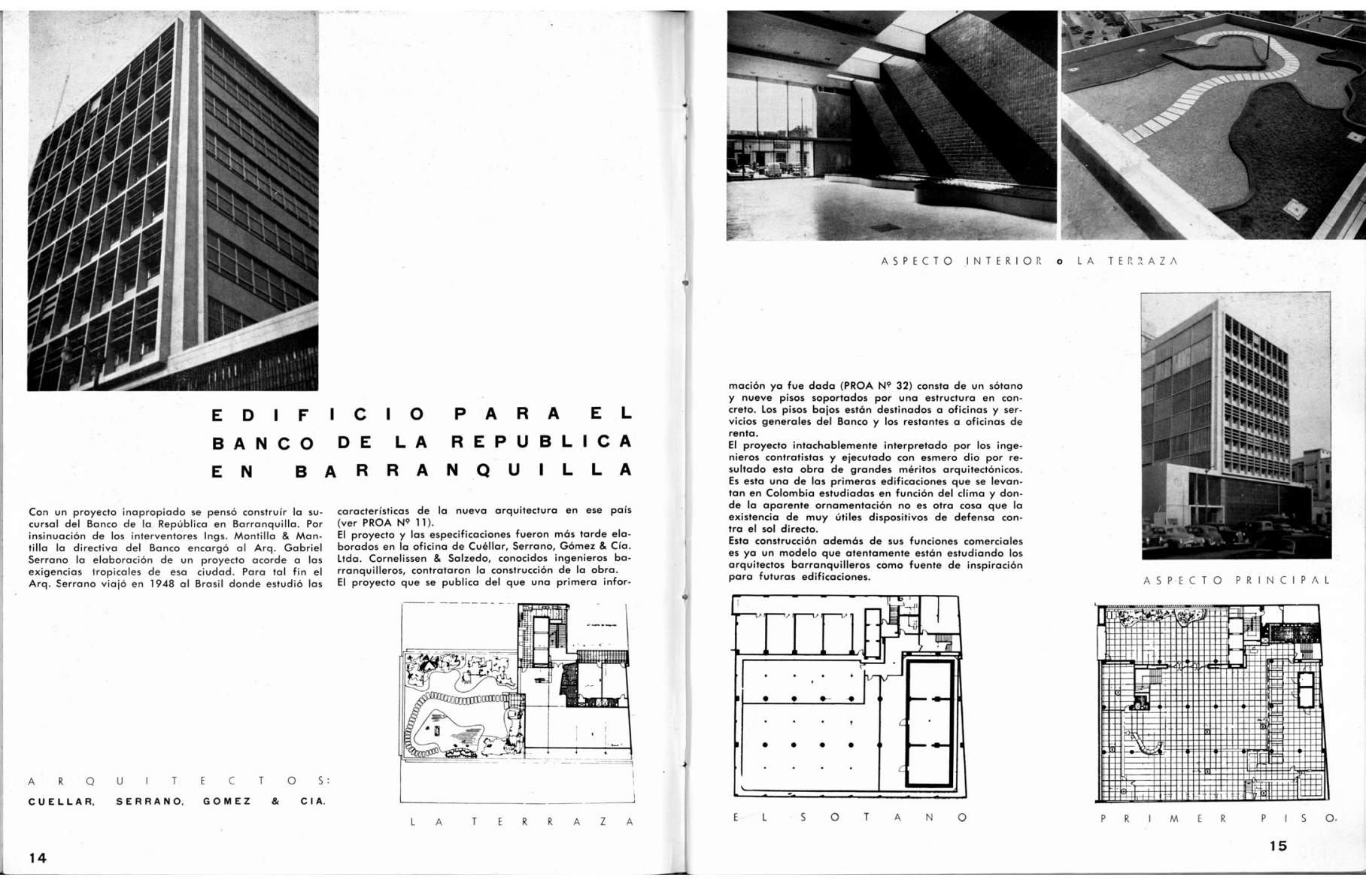

ASPECTO INTERIOR O LA TERRAZA

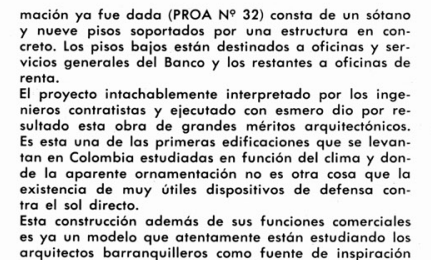
arquitectos barranquilleros como fuente de inspiración
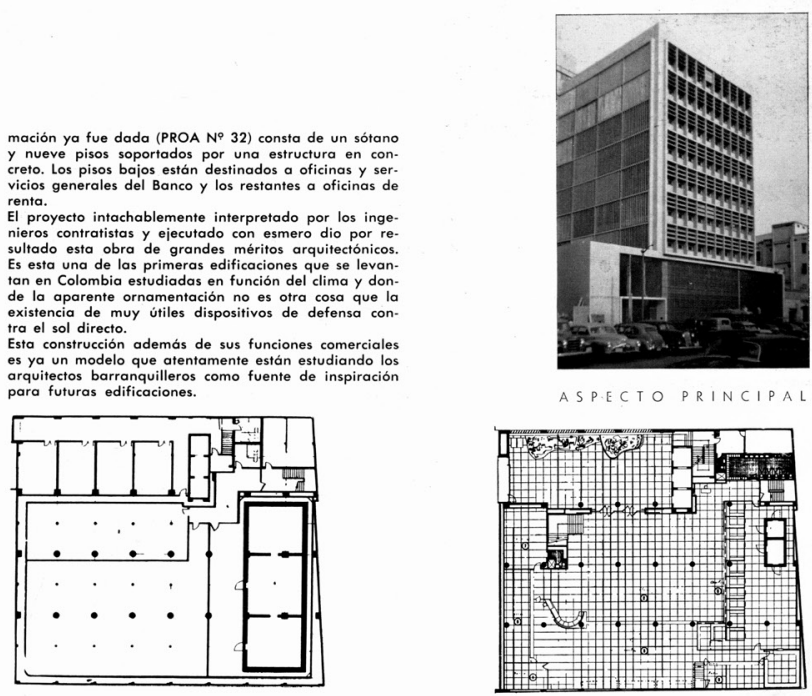

Figure 10. The Banco de República headquarter in Barranquilla, designed by Gabriel Serrano as leading architects of the firm Cuéllar, Serrano, Gómez \& Cía (1948-52) after he travelled to Brazil. Proa, 63 (1952), pp. 14-15. Courtesy of Proa. 


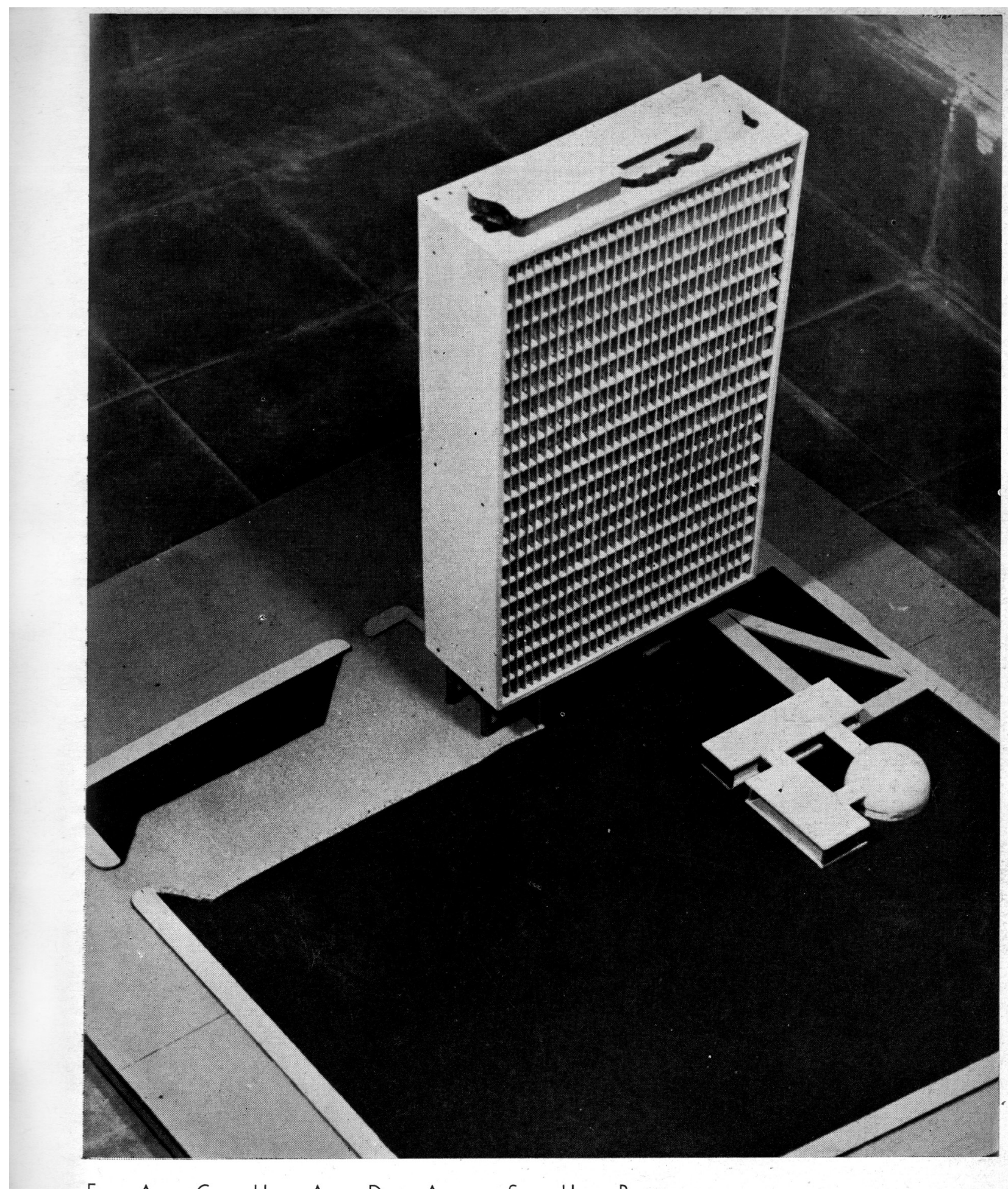

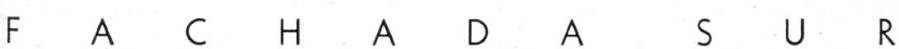

Todas las oficinas reciben el beneficio de las brisas y la buena luz. Desde ellas se podrá mirar el paisaje del río y la costa. El último piso corresponde al restaurante, que tendrá un jardín en su frente. En la parte correspondiente al primer piso, en el frente y hacia la mitad del edificio se ha proyectado un gran mural en cerámica. Las columnas en el primer piso se translucen a través del vidrio obteniendo en esta forma una continuación visual del jardín dentro del edificio y fuera de él. El revestimiento de dichas columnas y de los muros exteriores en materiales apropiados, darán un grato aspecto.

A R Q U I TECTOS

ROBERTO MCCAUSLAND

JOSE A. GARCIA

Figure 11. The original project for Barranquilla’s Municipal building by Roberto McCausland and José Alejandro García. Proa, 34 (1950), p. 20. Courtesy of Proa. 


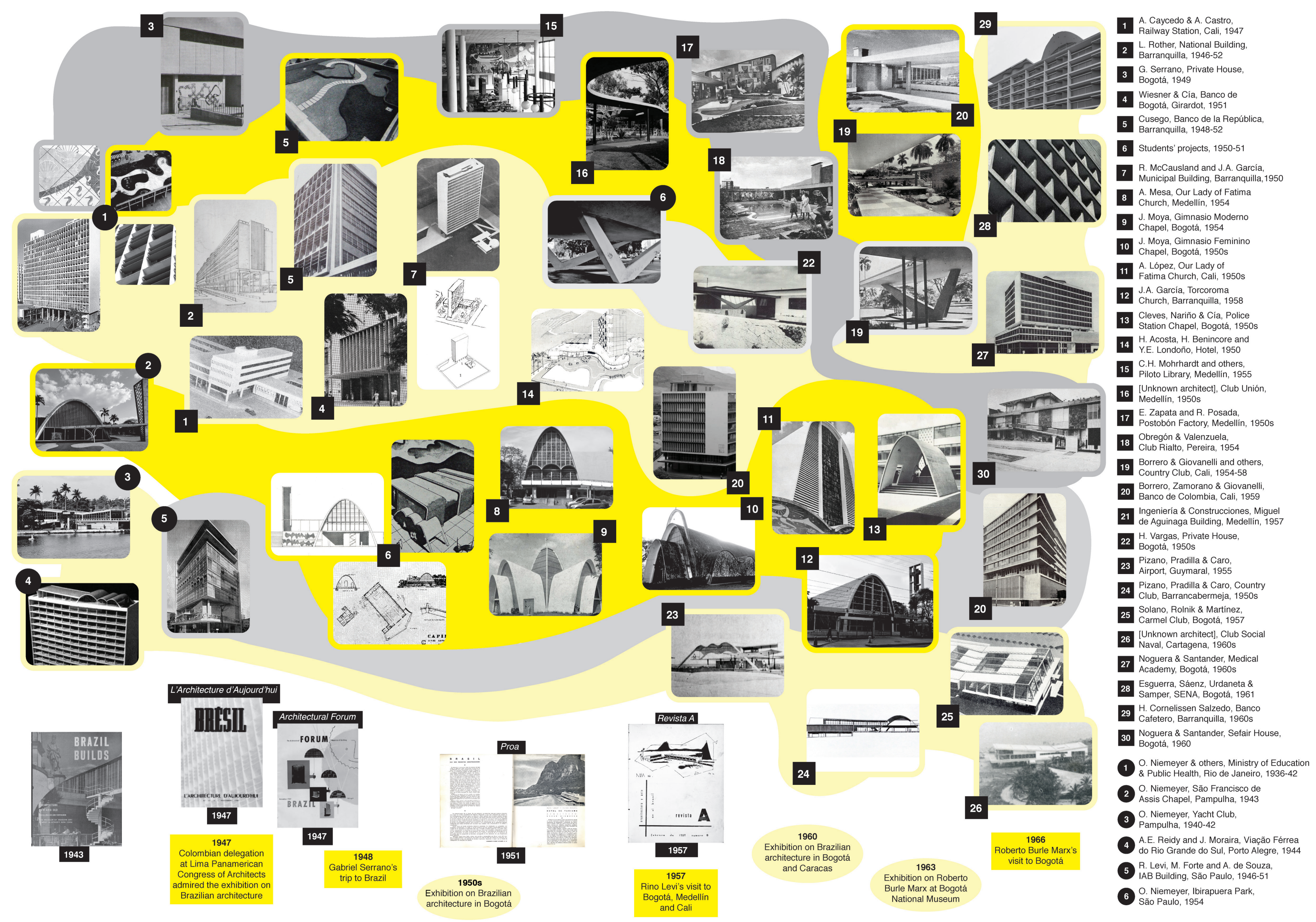

